Article

\title{
Devolved Regions, Fragmented Landscapes: The Struggle for Sustainability in Madrid
}

\section{Richard Hewitt $^{1, *}$ and Veronica Hernandez-Jimenez ${ }^{2}$}

1 Department of Geography, University of Alcalá, Calle Colegios 2, 28801 Alcalá de Henares, Madrid, Spain

2 Observatory for a Culture of the Territory, Department of Rural Planning, Polytechnic University of Madrid, Ciudad Universitaria 28040, Madrid, Spain;

E-Mail: vero.hj@observatorioculturayterritorio.org

* Author to whom correspondence should be addressed; E-Mail: richard.hewitt@uah.es;

Tel.: +34-635-917-168; Fax: +34-91-885-44-39.

Received: 30 March 2010; in revised form: 7 April 2010 / Accepted: 28 April 2010 /

Published: 5 May 2010

\begin{abstract}
This article reflects on the recent unsustainable land use changes in the Autonomous Community of Madrid and asserts the need for progress towards economically, environmentally and socially sustainable development models. Following research undertaken over the last six years there are encouraging signs of agreement between stakeholders and the problem has begun to "open up". Here a new phase of problem solving is initiated, in which particular tendencies toward unsustainability are identified using a variety of basic indicators. These "Sustainability Action Areas" can be targeted for collaborative sustainability initiatives involving groups of municipalities aggregated according to their response to particular indicators.
\end{abstract}

Keywords: sustainability; land use change; collaboration; local action areas

\section{Unsustainability of Land Use Changes}

Land use change is an inseparable part of the human exploitation of the earth and its resources. In Europe, vegetation changes observed at the end of the most recent Ice Age around 10,000 years ago 
marked the beginning of a process of anthropogenic land cover and soil modification and the eventual transition to agriculture, which probably originated in the southern Levant and Euphrates valley around 12,000 years ago [1]. Since this time, land use change has accelerated sharply in line with an exponentially increasing world population and rapidly evolving technological capabilities, bringing ever greater areas of the earth's surface under human control. However, bioproductive land, capable of sustaining the earth's ecosystems, is not limitless, and some types of land use change, for example extraction of non-renewable resources, are irreversible on a human timescale. The need, therefore, to manage the exploitation of the earth and its ecosystems in such a way that the planet may continue to sustain both human and animal life gives us the principal of sustainable development- "development that meets the needs of the present without compromising the ability of future generations to meet their own needs" [2]. Though sustainability in practice is often subdivided into narrower sub-categories emphasizing particular economic, environmental or social criteria, these problems are highly inter-related. Land use changes that jeopardize food production, ecosystem services or global climate are clearly unsustainable. Patterns of unsustainable land use change of this kind may be fairly easy to detect at the scale of a country, continent or large land mass. The difficulty arises at regional or local scales where there is no widespread agreement about what is causing the problem, or even, that there is a problem at all [3].

For example, European agriculture operates within the framework of a European agricultural subsidy model (the Common Agricultural Policy) which recognises that maintenance of European agricultural production at its optimum level is not economically sustainable. However, encouraging abandonment of productive land erases ancient farming traditions, empties the rural landscape, provoking social changes, and may drive other land use changes, such as urban sprawl, that are environmentally unsustainable [4]. In a scenario where agricultural land commands a much lower market price than urban land, farmers are anxious to sell to developers.

This is what has been happening in Spain, most notably in the Autonomous Community of Madrid (CM). The Land Law 2/2005 [5] (a modification of the Land Law 9/2001 [6]) of the regional government of Madrid facilitated the rapid conversion of non-urbanisable (usually agricultural) land not subject to special protection into urbanisable land. This may be acceptable to the European economy on one level (less economically unviable farmland) but it has serious environmental consequences, and may lead to unsustainability at the local or regional level as societies find themselves unable to adapt to purely economic top-down decisions. Antrop [7] reflects that landscapes evolve in response to economic and social needs. Economic, social and environmental sustainability are interlinked at the level of the landscape. These different aspects of sustainability in the landscape must be solved together, with each of the varying perspectives seen in their shared context [8] if progress is to be made in development that is genuinely sustainable at all levels. In Madrid, the collapse of the construction industry at the end of the property boom is at least partly related to the massive expansion of the sector for short-term economic reasons without thought to the long term economic, social and environmental consequences (See Figure 1). Both local and regional economies were initially boosted by the construction sector, only to be later submerged in recession. Just as overexploitation of natural resources causes future hardship, over-expansion of one sector without adequate provision for the future makes the fall even harder when it comes. 
Figure 1. Unemployment in the construction industry 2006-2008 (CM).

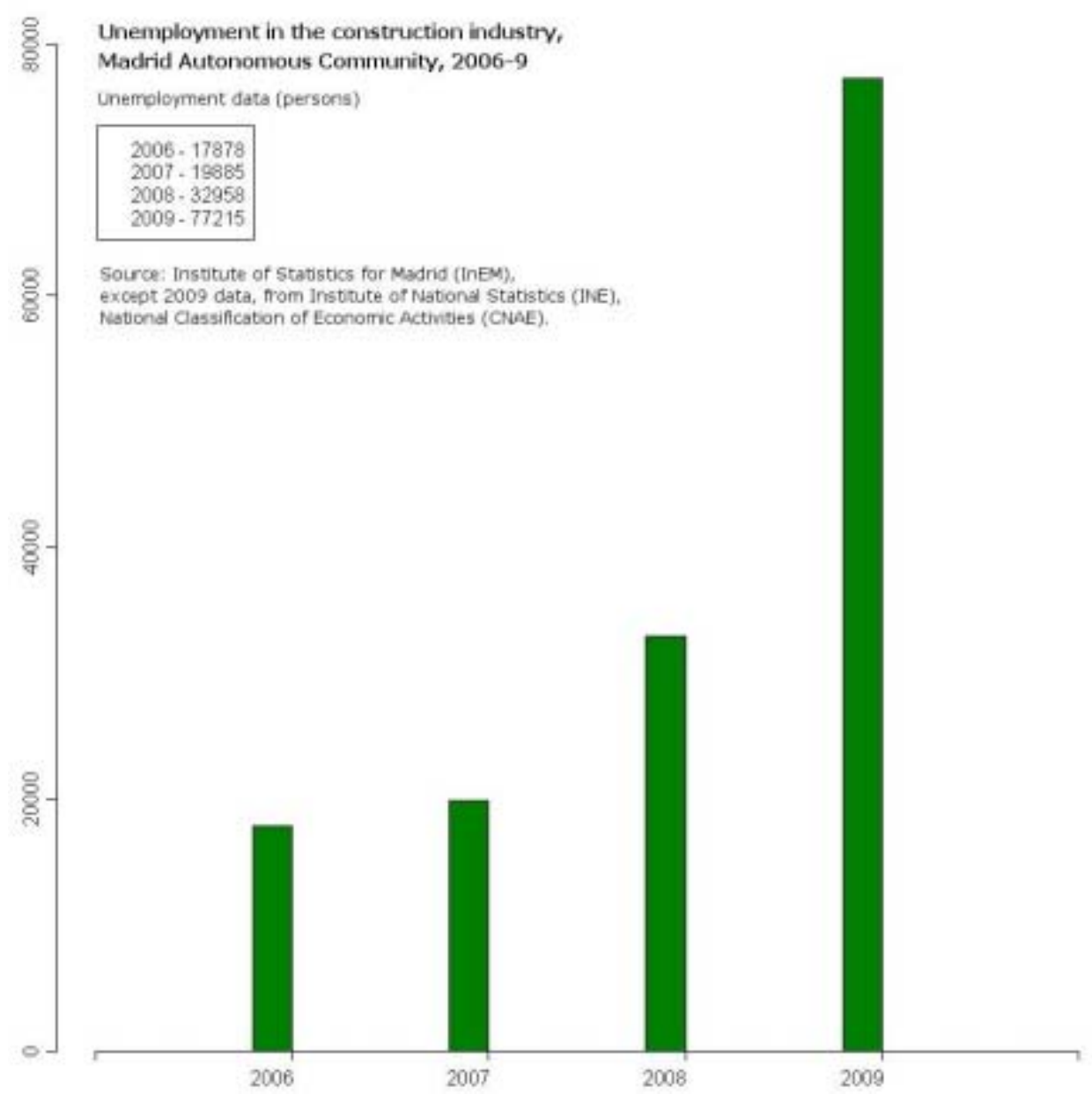

In practice, of course, integrating the different perspectives about sustainability and land use is difficult. The conflicting perspectives of many different interest groups must be taken into account and achieving consensus about these issues in a modern democracy like Spain is far from straightforward. The viewpoint of the farmer, the ecologist and the politician cannot become one and the same, no matter how globally conscious the farmer, no matter how sensitive the ecologist to the needs of the local economy, no matter how environmentally aware the politician.

In a six year program of research funded by the fifth and the sixth European Framework Programmes, investigators identified key stakeholders in the $\mathrm{CM}$ and attempted to negotiate collaboration and participation "buy-in" [9,10]. Under TiGrESS (Time Geographical Approaches to Emergent Sustainable Societies) in FP5, and its successor, ISBP (Integrative Systems and the Boundary Problem) in FP6, divergent perspectives and attitudes were brought to the discussion table. The researchers observed that highly conflicting viewpoints tended to bring negotiations to a standstill, where the problem domain becomes "locked down" [11]. In such a scenario, no progress is possible; powerful policy makers will push through their actions anyway, and all other groups are excluded from discussions or banished to the margins as troublemakers. Progress cannot be made unless excluded groups are brought back in to the circle and the problem is "opened up". In fact, despite what appears to be a frustrating lack of progress on many issues relating to sustainability, much "opening up" has already taken place in the CM (previously excluded stakeholders are becoming part of the debate), and 
it is now becoming possible to begin a new phase of problem-solving. It is time to move away from generalities to a discussion of "impacts, mitigation, compensation, and accommodation" (ibid) and begin making constructive attempts at a solution. The CM is now capable of moving towards a more sustainable development model [3].

In this article we take a step further down the line and address both the level of government appropriate for sustainable development initiatives to be instigated, and identify key areas of concern at which these initiatives should be directed. The current situation is reviewed in the light of sustainable development planning initiatives in other Spanish regions (i.e., Catalonia). We suggest that existing development planning arrangements are not sufficient to deliver sustainability actions without some form of broader territorial grouping within the Madrid region. The article is concluded with some recommendations for appropriate areas of action defined on the basis of concerns about sustainability at particular locations.

\section{Development, Change and Complexity in Madrid}

Much literature deals with the whole of the Autonomous Community of Madrid, and does not refer to districts or areas. There is no review of sustainability on a regional or local scale, and little comment about specifics. It is time to move away from generalities and open up the problem.

The CM is a self-governing (autonomous) region of $802,231 \mathrm{ha}\left(8,022 \mathrm{~km}^{2}\right)$ in the heart of Spain with the Spanish capital city at its center. Over the last 20 years, the region has seen massive infrastructure expansion and accelerated urban growth, coupled with a sharp decline in agricultural production, with large land areas, particularly non-irrigated arable land, being abandoned or converted to residential or industrial uses $[12,13]$. Though compliant with European Union economic and legal convergence criteria, the $\mathrm{CM}$ falls short of environmental and sustainable development criteria $[14,15]$. In the $\mathrm{CM}$, where land use change has been particularly dynamic, a substantial body of literature - much of it highly critical — exists documenting this phenomenon. The CM, together with Murcia and the Community of Valencia, is the Spanish region with the highest rate of urban growth [14]. Artificial surfaces (continuous and discontinuous urban fabric, industrial or commercial units, road and rail networks and associated land, airports, minerals extraction sites, dump sites, construction sites, green urban areas and sports and leisure facilities) increased by $47.7 \%$ between 1987 and 2000 [16], far beyond either national or European averages [17].

Madrid's sprawling development pattern has drawn criticism at European level on sustainability grounds, as much of the new urban fabric constructed since 1990 has been dispersed or discontinuous., with new low-density residential development outside the city's core areas requiring continued investment in expansion and maintenance of transport infrastructure (itself a driver of urban growth) and increasing dependence on the private car. Private vehicle use is especially high for transversal mobility, that is, journeys between built up areas on the outskirts of the core city, between towns on the fringe of the metropolitan area, and between outlying towns and villages in the wider region. Despite a higher percentage of journeys undertaken by public transport than in many other European cities, Madrid, nonetheless, is tending towards an unsustainable transport model [18].

Expansion of Madrid's infrastructure network appears to have acted as a driver for land use change, with a clear relationship between the rapid growth of the capital's infrastructure and land use change in 
spaces adjacent to new roads. Authors such as Serrano et al. and Lopéz de Lucio [19-22], emphasized the key role played by massive expansion of the road network in the dispersion of the population away from the old urban core and the development of leisure and retail spaces in peripheral areas. Decentralisation of commercial and industrial activities to outlying areas, accelerated by expansion of infrastructures, has been underway for some time $[23,24]$. These fringe areas, where the city "stops" and the country "starts", also called transition or periurban areas, are particularly susceptible to sprawling development patterns, with little control exercised over urban form and no consideration to sustainability. Here, land is often simply re-classified for urban development without opposition or impact assessment. New forms of very low density development have emerged, so called grandes superficies (large surface area developments) for industrial (large scale distributors) commercial and leisure (shopping centers, offices and entertainment complexes) $[25,26]$.

The Spanish Observatory for Sustainability (OSE) noted that land use changes have been most extensive in the immediate hinterlands of the big cities, mainly in formerly agrarian areas [16]. Although there are agrarian areas in the $\mathrm{CM}$, agricultural value has not been a factor in regional planning legislation. Nature conservation is managed in a confrontational way, with reserves protected from development, but no thought given to complementarity (the importance of what lies beyond the boundary of a protected area), or system resilience. Resilience, a system's capacity to cope with alteration and innovation [27,28], is an important consideration in sustainability of socio-natural systems [29]. The concept of resilience is important here because land use protection is unhelpful if it is not tied to land resource requirements (protecting everything effectively amounts to protecting nothing) or if it is so inflexible that it ends up being ignored.

Land use change analysis at the level of the region by authors such as Aldana [30], OSE [16] reports and Plata et al. [12] clarified important patterns that had already been emerging from earlier studies. Aldana [30] investigating land use change between 1987 and 1997, noted significant urban expansion orientated along road and rail networks and a general tendency toward dispersed urban development. OSE [16] reported rapid growth in artificial surfaces (urban, industrial and commercial areas transport, mines, quarries and construction sites and other non-vegetated areas such as sports and leisure facilities) over the period analyzed (1987-2000), to the detriment of forested and agricultural areas. Plata et al. [12], investigating land use change between 1990 and 2000, noted a strong increase in urban areas, principally low density residential units. Significant changes to forested areas through gains from agricultural land and losses to urbanization, although these land use areas did not register net loss over the time period. Traditional agricultural areas had experienced serious net losses. Losses to both forested and agricultural areas were shown to be occurring principally less than 500 meters from artificial areas in 1990. Significant expansion of mining and quarrying activity was also noted over the 10 year period.

Despite vigorous debate and dialog about Madrid's unsustainable growth, the only factor to have any effect at all in slowing the pace of development has been the recent recession. The CM was hard hit by the deteriorating economic climate in Spain and elsewhere, and the booming construction industry, sustained by a permissive land-planning model operating at a very devolved level of governance, collapsed [31,32]. 


\section{The Gap between Land Planning Regulations and Land Planning in Practice}

Despite considerable effort over the last 20 years in producing laws, directives, urban planning regulations and other legal instruments related to landscape-land uses, transport, water, rural development and energy - all of this has yet to bear fruit in terms of concrete actions in the territory [33]. The failure to approve land planning tools at regional government level means that 59\% of the Spanish territory is still managed without appropriate land planning instruments. Exceptions are Catalonia and the Basque Country; both autonomies are working on their sectorial plans, supra-municipal plans and other specific (i.e., metropolitan) area plans. Hildenbrand [34] notes that the conflictive relationship between regional and local powers makes land management at a municipal level very difficult.

Even in the context of disputed competencies and documents awaiting approval, there is now so much legal information and precedent that it should still be possible to develop a single, transparent and functioning regional plan. Nonetheless, the CM remains without such an invaluable document, despite attempts at its creation since the 1970s with the "Special Plan for Protection of the Environment of Madrid". Later efforts in the early 90s under the socialist's government in the region $[35,36]$ also failed to define an effective regional framework. Subsequent attempts have met with no greater success. It is suspected that lack of political will is largely to blame. One researcher has observed that "...really the clearest strategy of the Community of Madrid in the last decade has been to neither define nor set down in a public document their project for the territory. It would be appropriate to say that the absence of a project for the territory is perhaps the most explicit project of the successive regional administrations..." [37].

This lack of supra-municipal land planning tools directly affects land use change processes, which take place without any formal direction, independent of the strategic value of the land and resources (for instance: fertile soils located in the river basins also have been used for urban development, as, for example, in the case of the Henares river corridor), and the essential inter-relationship between city and its territory is ignored [38,39]. Clearly, ever-expanding infrastructural networks increasing private car use, sprawling residential development, and loss of agricultural and natural areas all constitute threats to sustainability. These problems are of serious and legitimate public concern, and even in the short term, may substantially affect citizens' quality of life.

However, the absence of territorial planning in any legally enforceable sense is defended by the administration of the CM, which adopts one of two positions, either arguing that proper development planning is neither useful nor necessary in the region, or, alternatively, insisting that such a plan already exists, despite the abundant evidence to the contrary. Planning chiefs have preferred to question the practicality of implementing sustainable development initiatives. Leboreiro, Sub-Director of Regional Planning for the CM has argued that "the land planner may take as his starting point the paradigm of sustainability without taking into account the fact that this paradigm may be accepted by academics and professionals, but not necessarily by the rest of society" [40]. While this is a worthwhile observation, it is questionable whether Madrid's trajectory of increasing unsustainability is really a matter of democratic choice, or whether society, represented through the municipal government, lacks the appropriate tools and information to make informed choices. Public participation is virtually absent from the planning process, despite the fact that, according to recent 
surveys, the CM's inhabitants did notice significant changes in their territory [37]. The kind of public participation in local planning decisions reported by Deal and Pallathucheril [41] remains non-existent in Madrid.

While this noisy and unproductive debate continues in the region, other Spanish Autonomous Communities have been hard at work to build a more inclusive and sustainable development model. Catalonia has developed territorial planning tools whose main aim is to control urban expansion in the region [42]. According to Nel·Lo, Director of Territorial Policies at the Regional Government of Catalonia, this new territorial policy brings to an end a long period of scant supra-municipal planning by developing strategies for open spaces, infrastructures and control of urbanization in specific areas such as the metropolitan area of Barcelona, and other administrative units characteristic of Spanish devolved government. The current Catalan regional government aims to recuperate the oldest territorial system which divided Catalonia into territories known as veguerías. The regional government has established territorial action plans for each of these old divisions in order to facilitate supra-municipal planning and explore new ways of planning linked to historical identity and values. This territorial division has been recently adapted to the current situation and seven veguerías have been approved, named as follows: the metropolitan area of Barcelona, Girona, Alt Pirineu i Aran, Lleida, Comarques Centrals, Camp de Tarragona, and Terres de l'Ebre. Clearly, this is a challenging multi-stage process requiring consensus between different levels of public administration. In Barcelona, progress has already been made. As the economic powerhouse of Catalonia, the successful cooperation (including a public participation phase) between the 165 municipalities that make up Barcelona's metropolitan area to approve such a challenging plan is an extremely important step forward [43].

In Madrid, despite the abundance of decision tools, instruments and regulations ready and waiting to support a process of public participation and negotiation, power relationships between municipal, regional and national levels of government, consistently prevent the machinery being put into action [33]. As Cartledge et al. [11] have argued, it is impossible to "close down" the conflict and move towards implementation if no consensus was achieved in the previous stage. We seem to be locked in a cycle of conflict. However, if negotiations can be maintained until all the parties raise their concerns about emergent problems, progress can be made. It is not of course possible to know before opening up a problem that it will necessarily be possible to bring it to an end. There is potential both for information to flow from bottom up, causing problems to emerge, as well as for information to flow from top down, closing down problems and starting the implementation phase.

Madrid faces more or less the same challenges as all capital cities, i.e., managing resources while resolving political and economic conflicts of interest and responding to supranational and national laws while maintaining political consensus. Normally this would involve impact, mitigation, compensation, or accommodation states, but in the context of the current recession all of these stages are likely to be more difficult than usual. However, as we noted earlier, considerable "opening up" has already taken place. In May 2009, Madrid's land planning model was discussed and debated in workshop sessions extending over three days by a diverse range of stakeholders, including civil servants, local and national politicians, ecologists groups, local action groups, planners, academics, farmers and farmers representatives and rural development experts. Results from both TiGrESS and ISBP [9,32] reach the same conclusions about the role of consensus and participation in regional land use 
management - stakeholders are likely to be more strongly motivated to harmonize regional planning and make agreements for efficient participatory networks if they are involved from the outset in developing planning tools. Thus, now more than ever, it is essential to look at the right level of governance in a devolved country like Spain.

\section{The Importance of Working at the Appropriate Level of Governance}

Under Spain's devolved government system, the smallest administrative unit (the municipality) is responsible for development in its territory. Where overarching planning controls at the level of the autonomous community are not implemented or are not effective, as we have seen in Madrid, local interests and impacts tend to supplant the interests of the wider community. However, the example of Catalonia shows that progress can be made, if we are prepared to look at the territory in innovative ways. Sustainable development is one such area in which the wider community can benefit, but only if local interests can be encouraged to work together. To do this, it may be necessary to create new grouping of geographical units or, as in the case of Catalonia, invest ancient ones with new functions. The Madrid region's own administrative limits are ancient, only constitution of the area they circumscribe as an autonomous community is in any sense new (Law of Autonomous Communities in the framework of the Spanish Constitution of 1978) [44]. The boundaries of today's Autonomous Community of Madrid (CM) were in place by 1833 when Spain was divided into provinces, Madrid province at that time forming part of New Castile (Castilla La Mancha). It might be imagined therefore that this historic administrative unit would contain some agreed historic sub-divisions that could serve as indicative groupings for the purpose of defining shared territories, such as comarcas. Indeed, in the CM, as elsewhere, comarcas are to be found, generally grouping between 15 and 30 individual municipalities (Figure 2) into a single unit. Unfortunately, the boundaries of these comarcas themselves are not anywhere clearly defined - there is no official modern definition of what exactly constitutes a comarca in the CM, and the exact limits of a comarca depend as much on perspective (tourism, history, physical features or landscape characteristics) as on administrative convenience. The character of these comarcas in the $\mathrm{CM}$ is very different to other regions in which comarcas have a clear identity based on territory, language and heritage. In the Madrid region, there are, for example, comarcas defined for purposes of tourism, forestry areas, rural development areas and landscape areas defined by modern landscape researchers [45]. At any one time, it is possible to attain at least five possible territorial sub-configurations for the $\mathrm{CM}$, no one more valid than the other, and none of which have any formal administrative responsibility. If a response to the fragmented and devolved sphere of action where every municipality acts for its own benefit is sought through grouping municipalities into meaningful sub-territories, comarcas are clearly not the answer.

There do exist, however, regional subdivisions, which although not recognized as administrative divisions in the normal sense, do group municipalities with common characteristics to achieve shared goals. Regional policy initiatives within the European rural development programme (LEADER, PRODER, etc.) are co-financed with member countries and administered through the Local Action Groups (GAL) (Figure 3). These groups act as promoters of local development strategies as well as intermediaries between local and regional administrations. These groups are formed from groupings of municipalities with common territorial objectives which resemble (though do not exactly respect) in 
some senses, the comarcas. The great difference, however, between GAL territories and comarcas is that, unlike the latter, GAL territories are administrative groupings recognized by the regional government, and as such, have genuine political influence, albeit in a limited sphere of action. It can be suggested that some concerted action towards a more sustainable approach to land use change might be achieved within a similar framework. Indeed, rural development in the CM is currently under review by the regional government in the light of a new national law of Sustainable Rural Development [46], requiring Autonomous Communities to establish their own Sustainable Rural Development Plans (PDRS) for 2010-2014 reinforcing the EU funding for rural areas and the countryside with government funding.

Figure 2. The 179 Municipalities of the Autonomous Community of Madrid.

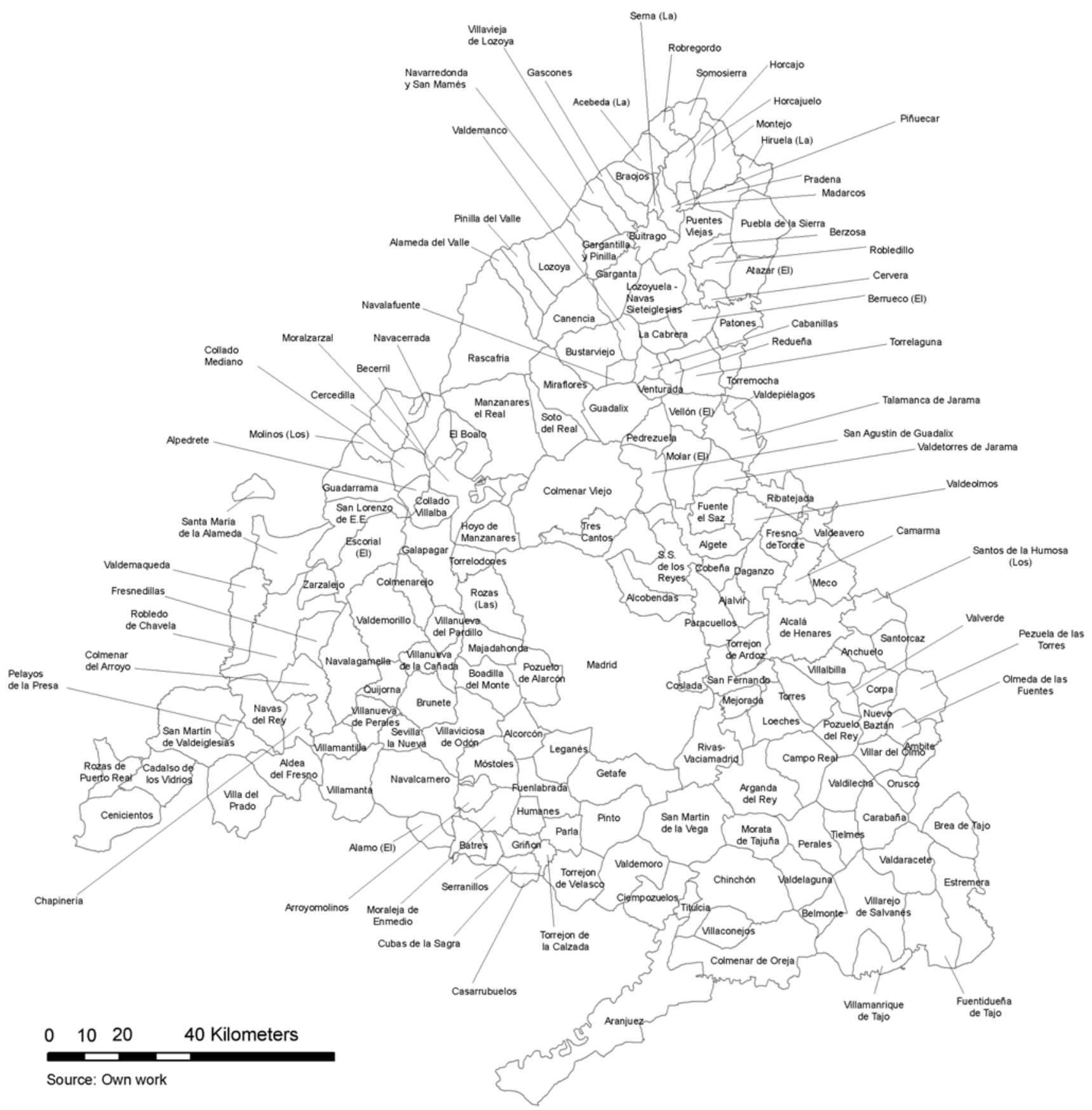


Figure 3. Local Action Group territories in 2009.

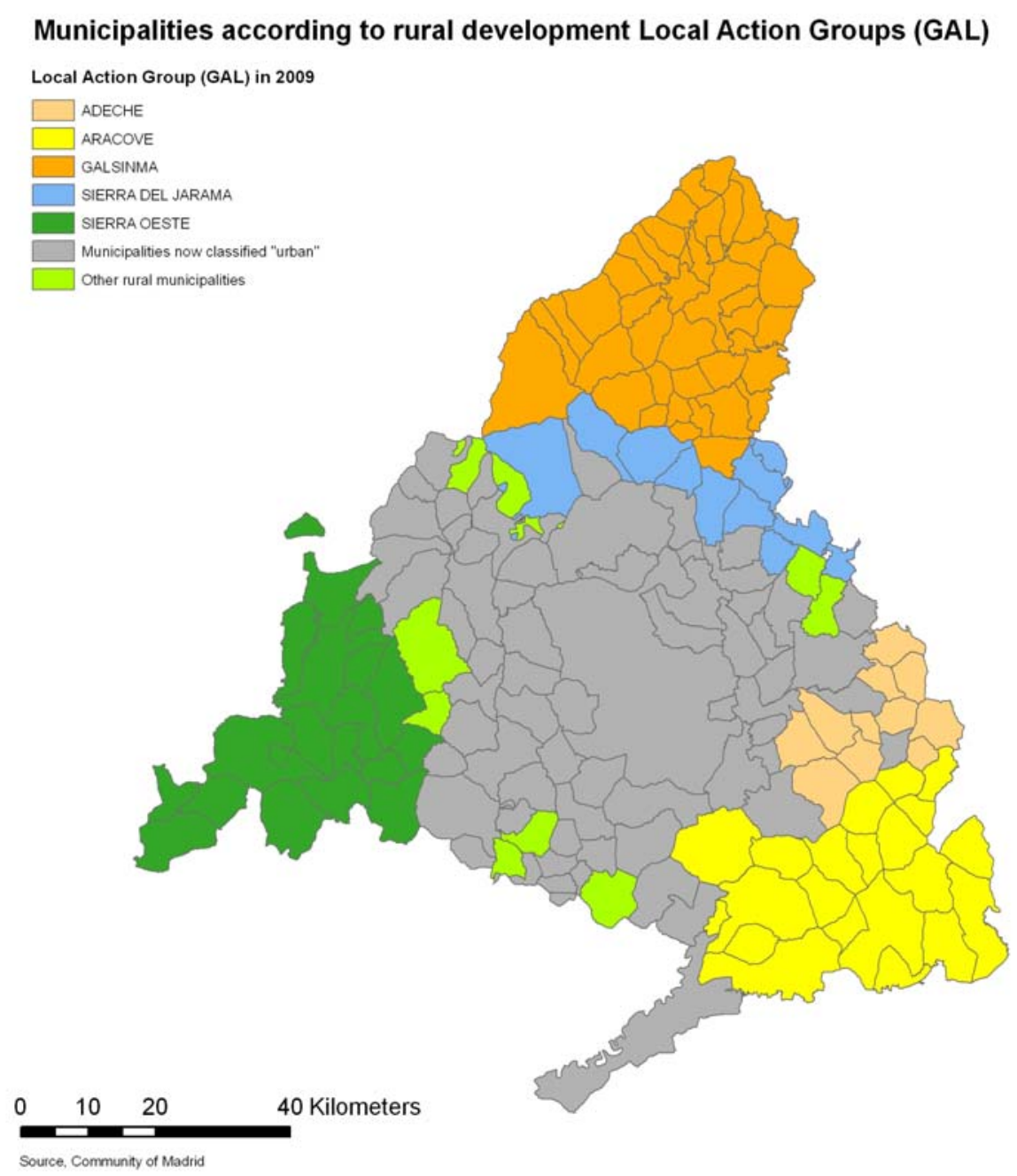

GAL territories are defined and organized to reflect local conditions and local preoccupations, and all are united by some common criteria, even if this is simply the desire of neighboring municipalities to work together. Usually, however, these criteria relate to shared rural origins, history or circumstances. They play a significant role in sustainable rural development as well as in revalorization of cultural and natural heritage. The Local Action Group for the Sierra Norte (GALSINMA), for example, broadly respects the administrative divisions of the historic territory of Somosierra [44,47,48]. The Local Action Groups have diversified over time. The first Rural Development programme (1995) of the Madrid region recognized only three Local Action Groups: Sierra Oeste de Madrid (SIERRA OESTE), Comarca de las Vegas (ARACOVE), and Sierra Norte de Madrid (GALSINMA). Then, in the second Rural Development programme (2002), the number of Local Action Groups increased to occupy almost all the territory except the Metropolitan Area of Madrid, with three more Local Action Groups: Campiña del Henares (ADECHE), Sierra de Guadarrama y Alto Manzanares (ADESGAM), and, Sierra del Jarama (SIERRA JARAMA). Figure 3 shows Local Action Groups in their present configuration, with regard to the national law in Sustainable Rural Development (Law 45/2007) [46]. ADESGAM will stop receiving funding because of the new indicators of rurality, and this is why it does not appear on the map of Local Action Groups 
(Figure 3). This new situation is a result of urbanization over the last two decades in the region. The municipalities belonging to ADESGAM have become urban municipalities according to the indicators (e.g., distance to the main urban nuclei, agrarian land and agrarian population, percentage of protected natural areas, etc.) that the national law (45/2007) [46] has established.

Agenda 21 (another tool for sustainability) emerged from the international community out of concerns about the appropriate scale of action for sustainable development. In 1992, in the United Nations Summit for Environment and Development (The Rio Summit), an agreement was reached within the international community with regard to local administrative methods for planning sustainable development from the lowest level of government. However, at the implementation stage, individual local priorities have tended to take precedence over collective action for sustainable development [49,50]. For example, Local Agenda 21 strategies might lay down detailed plans for waste management centers or car parks, but not consider initiatives to reduce production of waste or improve public transport between local towns and villages. Agenda 21 is already implemented or in progress in many of the CM's municipalities (Figure 4).

Figure 4. Municipalities with Agenda 21 completed or in progress.

\section{Municipalities with Agenda 21}

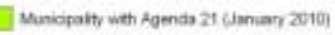

7 Mniapaity withoct Agenda 21 (Gamuary 2010$)$

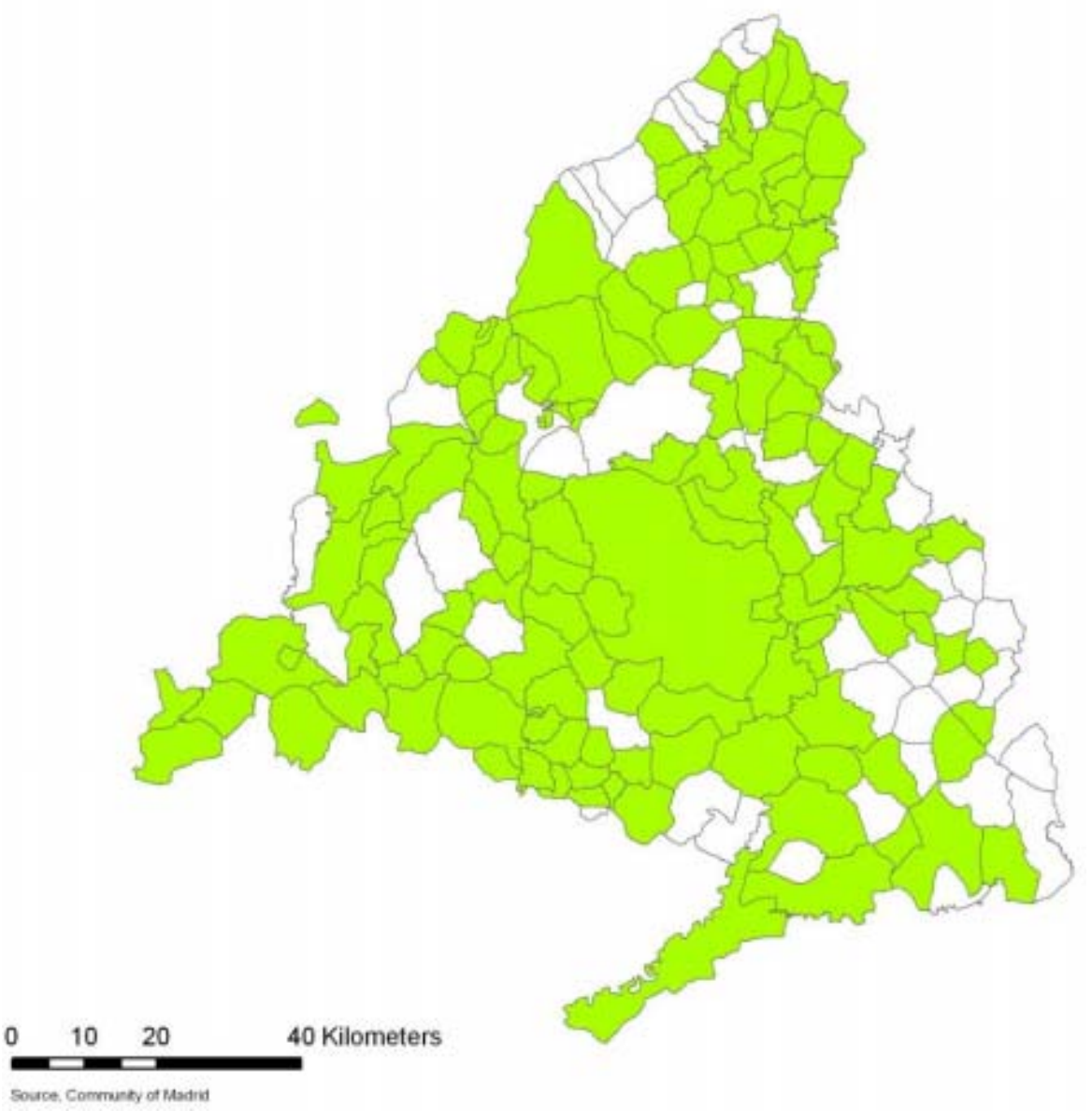


Following this lead, in the struggle for a sustainable approach to land use and development, it makes sense to try to define territories through precisely the characteristics that make sustainability urgently necessary. Such a process of definition is not merely a problem of regional geography, land use changes must be interpreted through the lens of society and economy as well as landscape [51].

\section{Choosing the Appropriate Scale for Sustainability Action}

By stating clearly the areas of the Madrid region which are of concern from a sustainability point of view, it becomes possible to start working towards a solution [11]. In the following paragraphs, with the objective of defining "Strategic Areas for future Action", we identify some key zones which we consider to be of concern from the point of view of sustainability.

Perhaps the most widely reported threat to sustainability in the CM has been the seemingly unstoppable extension of housing, industry, mining and quarrying, infrastructures and other related "artificial" non-agricultural activities into all areas of the territory. Most literature is devoted to analytical description of this process, leading to explanations as to why this has occurred. Some authors note the threats these changes pose for sustainable development [22,52]. It is not so much that tendencies like massive development of the transport network [19-21], increasing dispersion of residential areas [18], expansion of mining and quarrying [12], relocation of industrial areas from core to periphery [23], and changes in distribution of goods and services [25] are in themselves undesirable, but that collectively they lead to a transformation of landscape, economy and society that accelerates natural resource use in a way completely unknown at any time previously. By identifying the areas where this transformation has been most accelerated, we try to identify zones of specific concern for future action.

The indicators we have selected for discussion below are, in our opinion, those which exhibit the strongest evidence for transformation towards an unsustainable configuration, and which were, at the time of writing, most easily available. In most cases it would have been possible to select other data sources for the same information. Allowing for differences of scale or emphasis, all alternative sources, as far as we are aware, demonstrate the same trends. Though there may be much debate about the importance and significance of the dynamics discussed, the data are all derived from widely available, accepted and reliable national and international sources, and the tendencies they show are largely uncontroversial. Data unavailable to us at the time of writing, but which would be of great interest to review for their implications for sustainability include, water use and water sources [22], expansion of the infrastructure network [19-21], and the expansion of the logistics sector [25]. Research into the sustainability implications of new habits of consumption and the increasing phenomenon of out-of town retail and leisure parks is in progress [26].

\subsection{Growth of Artificial Areas 1990-2000}

Land use and land cover mapping datasets like CORINE land cover [54] are appropriate for identifying areas of the territory where changes have been most dynamic. The CORINE 1990-2000 datasets were analysed using GIS software. Land cover in 1990 falling into the CORINE artificial land cover category was extracted by municipality, and expressed as a percentage of the total land area of each municipality. This process was repeated for land cover in 2000. The percentage of each 
municipality occupied by artificial surfaces in 1990 was compared with the percentage occupied by artificial surfaces 10 years later. The difference between the two percentages $(\%$ artificial land cover $2000-\%$ artificial land cover 1990) was then plotted by municipality (Figure 5 and Appendix 1).

Figure 5. Growth of artificial areas 1990-2000.

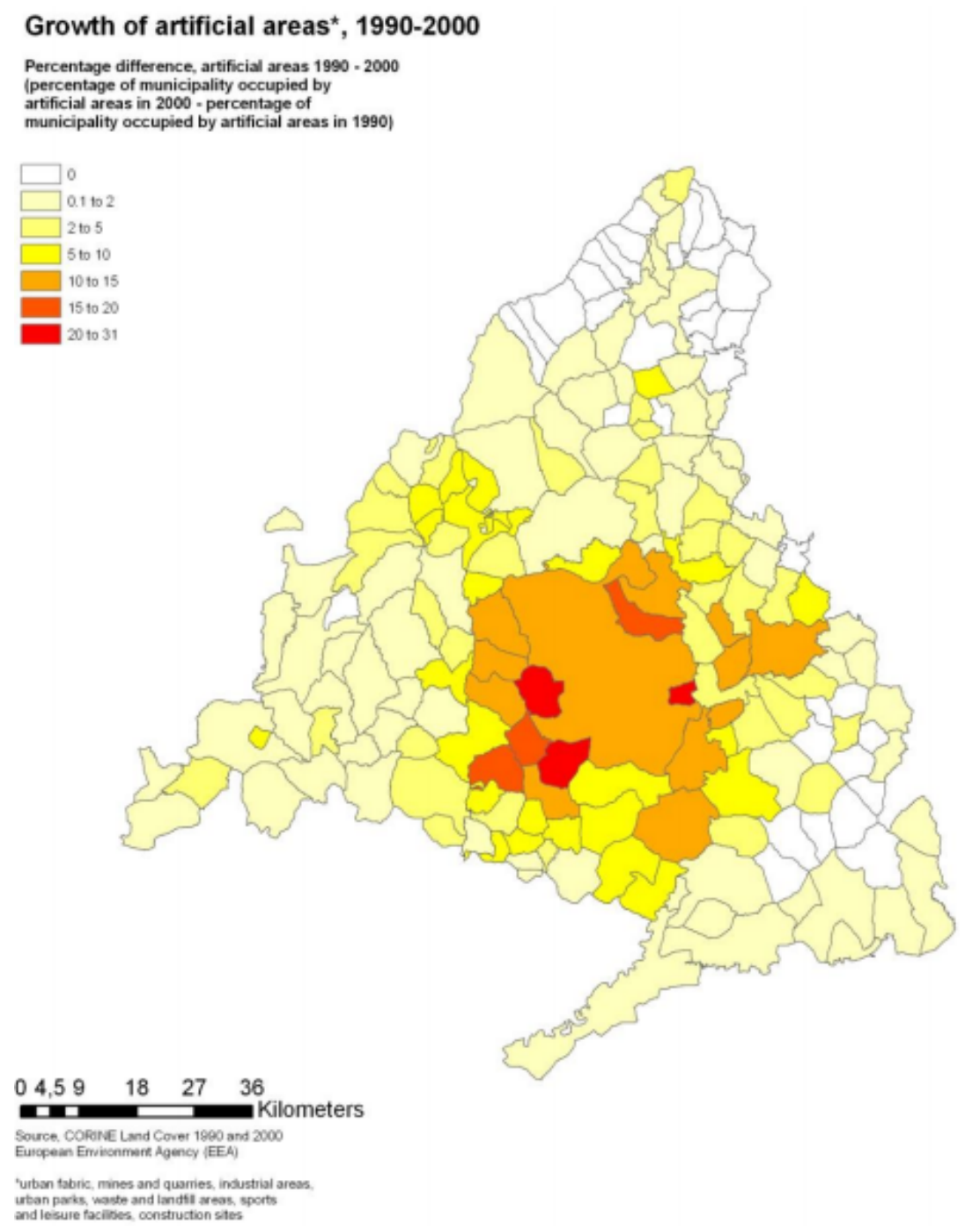

Though CORINE land cover 2006 was still not available at the time of writing, evidence from other sources [52] suggests that the trends identified here have almost certainly continued in the time period 2000-2006. Figure 5 depicts the sharpest growth in percentage of land area occupied by artificial surfaces. It can be noted that those municipalities shown in yellow have increased their percentage of artificial surfaces by $5 \%$ or more, and that, in the red shaded areas, municipalities in 2000 have $20 \%$ more artificial land than in 1990. In the south-west corner of Madrid core city, four municipalities are shown in dark orange and red (Alcorcón, Móstoles, Leganés and Pozuelo de Alarcón). These are historic urban development zones at the city's fringe, which have seen planned, and mostly high-quality urban development since the 1970s. All except the latter (Pozuelo de Alarcón) are served by the southern branch of the city's metro system, a cheap and efficient service which does more to reduce private car use within the metropolitan area than practically any other European metro system [18]. If urban development in Madrid is to be sustainable, we should look to locate it here. The 
crescent shaped municipality to the north of the core city is Alcobendas, a historic peripheral industrial area served by both the metro system and a long-established motorway (N-II). It is not surprising growth here has been extensive.

To the east of the core areas, the other red and orange shaded municipalities of Coslada, Torrejón de Ardoz and Alcalá de Henares are all well-served by local short distance train services (Cercanías). These are, at least, historically developed areas of lower-income residential and industrial use, even if the development pattern here has been excessively linear (dispersed along the Madrid - Guadalajara infrastructure corridor) and the fertile terraces of the river Henares have been needlessly built-up with industrial and warehouse units.

Areas of concern, from the point of view of sustainability, is the increasing occupation by artificial land areas, of zones well away from traditional population centres or poorly served by public transport. In this bracket, the group of municipalities to the north west of Madrid, Torrelodones, Moralzarzal, El Boalo, Becerril de la Sierra, Collado Mediano and Alpedrete, are of interest. These are traditional areas of tourism and second homes, but also occupy an area of outstanding natural value, within, or adjacent to, the Sierra de Guadarrama. Is it really desirable that these areas should grow so much?

To the south of the capital, artificial land areas in Rivas-Vaciamadrid and San Martín de la Vega have increased substantially, along with all of the municipalities along the line of the N-IV motorway to Andalucía (Getafe, Pinto, Valdemoro, Ciempozuelos). With the exception of Getafe (an older peripheral built-up area like Alcorcón), these municipalities are lately emerging as pockets of light industry along road and rail routes. The development of these areas is likely to be related to the increasing tendency for industry and services (especially large scale distribution centers) to relocate away from the city's core areas, a well-documented driver of urban sprawl [14].

Many further observations could be made that are beyond the scope of this article. However, it is already possible to define, and group together municipalities that share particular dynamics on the basis of sustainability criteria independent of any historical or administrative allegiances.

\subsection{Loss of Natural and Agricultural Areas 1990-2000}

The land area occupied by artificial surfaces has increased between 1990 and 2000. Since there are no wetlands in the CM, and water bodies have not increased over this time period, this increase must be at the expense of the two remaining CORINE level 1 land use categories, namely: natural and agricultural areas. This is indeed the case, as detailed analysis of land use and land cover change in the $\mathrm{CM}$ over this time period confirms [12]. This exchange of land between the various agricultural and natural categories is quite complex (principally because abandoned agricultural land tends to be difficult to distinguish from, or to revert entirely to, natural, or unmanaged land).

For this reason, the two categories are grouped together, in what is essentially the inverse of the previous map (Figure 6 and Appendix 2). It is included to emphasize the fact that unsustainability is not purely related to development, but also its inverse - sprawling development may lead to inefficient resource use through over-extended supply networks, while loss of agricultural land reduces the possibility of shortening supply chains by fostering local production. 
Figure 6. Decline of agricultural and natural areas 1990-2000.

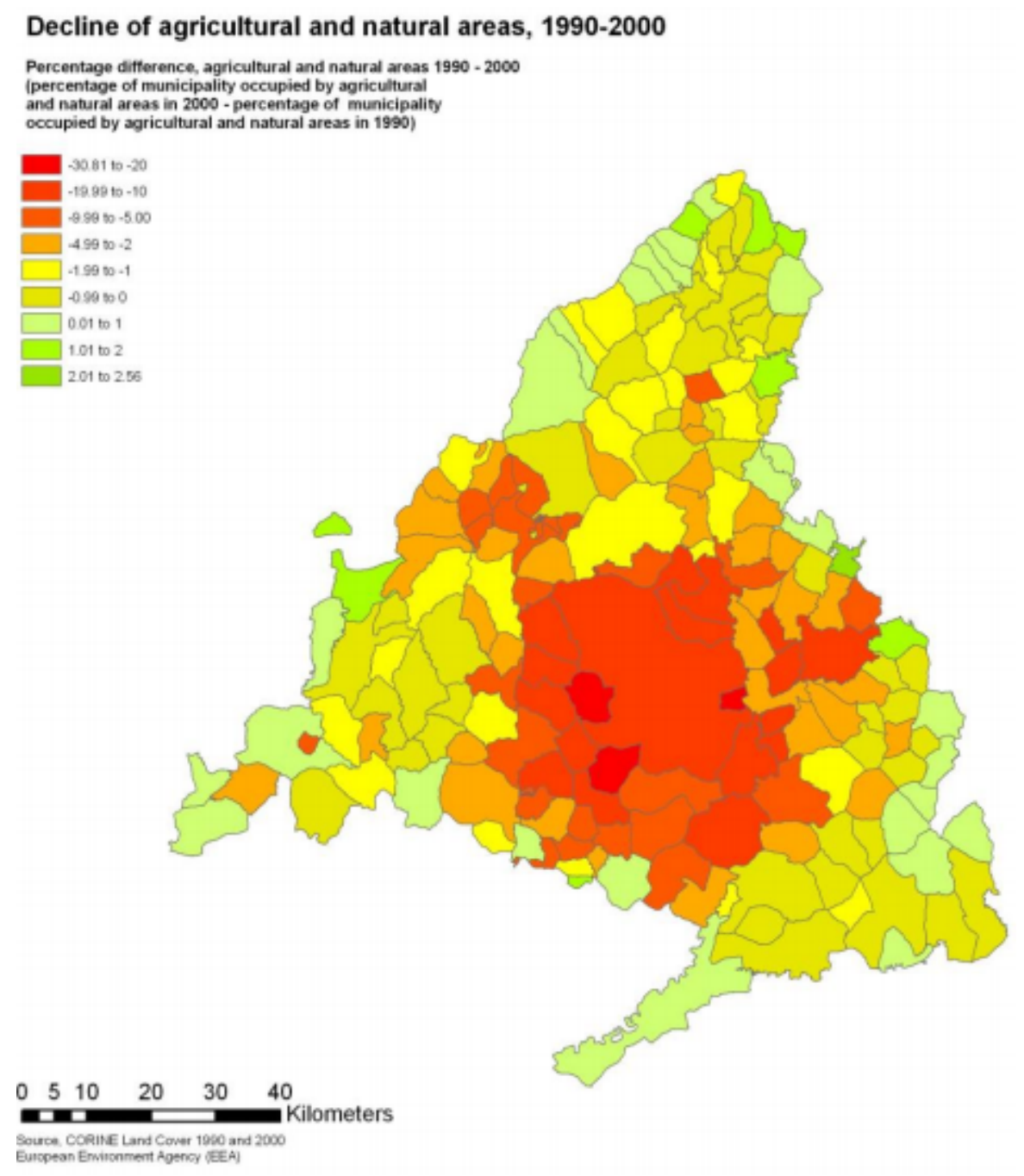

\subsection{Economic Sustainability-The Example of the Construction Industry}

Critics of development policy in the $\mathrm{CM}$ have drawn attention to the unusually non-interventionist approach of the regional government with regard to proper regional spatial planning. Some authors suspect that this peculiar situation has been maintained because it "has proved very profitable for some political insiders" [3].

The lack of political will to interfere with the short-term financial interests of the construction boom has tended to frustrate any form of innovation ( $i b i d$ ). Prior to the crisis, it was possible for politicians to argue, against a background of voter apathy around sustainable development issues, that there was a real risk of harming the regional economy by implementing tighter development control. With the regional economy in boom on the back of the construction industry, a lack of willingness on the part of politicians to interfere in a massive wealth creation scheme on the grounds of debated principles of sustainability, is, if not justifiable, at least comprehensible. But sustainable development, if properly handled, is anything but anti-economic in the long term. Sensible handling of the construction boom cycle might have allowed transfer of genuinely skilled workers across to related industries (such as 
renewable energy), instead of a gigantic leap in regional unemployment and thousands of empty homes in sensitive natural areas.

In short, if proper strategic planning was deemed by politicians as not in the best interests of the regional economy before the economic crisis began, the continuing recession in Spain, is, if nothing else, a good opportunity to review this approach and begin to implement some genuine progress towards sustainable development. Unsustainable land use change in the CM has had economic, as well as environmental consequences (Figure 7 and Appendix 3).

Figure 7. Unemployment growth in the construction industry 2006-2009.

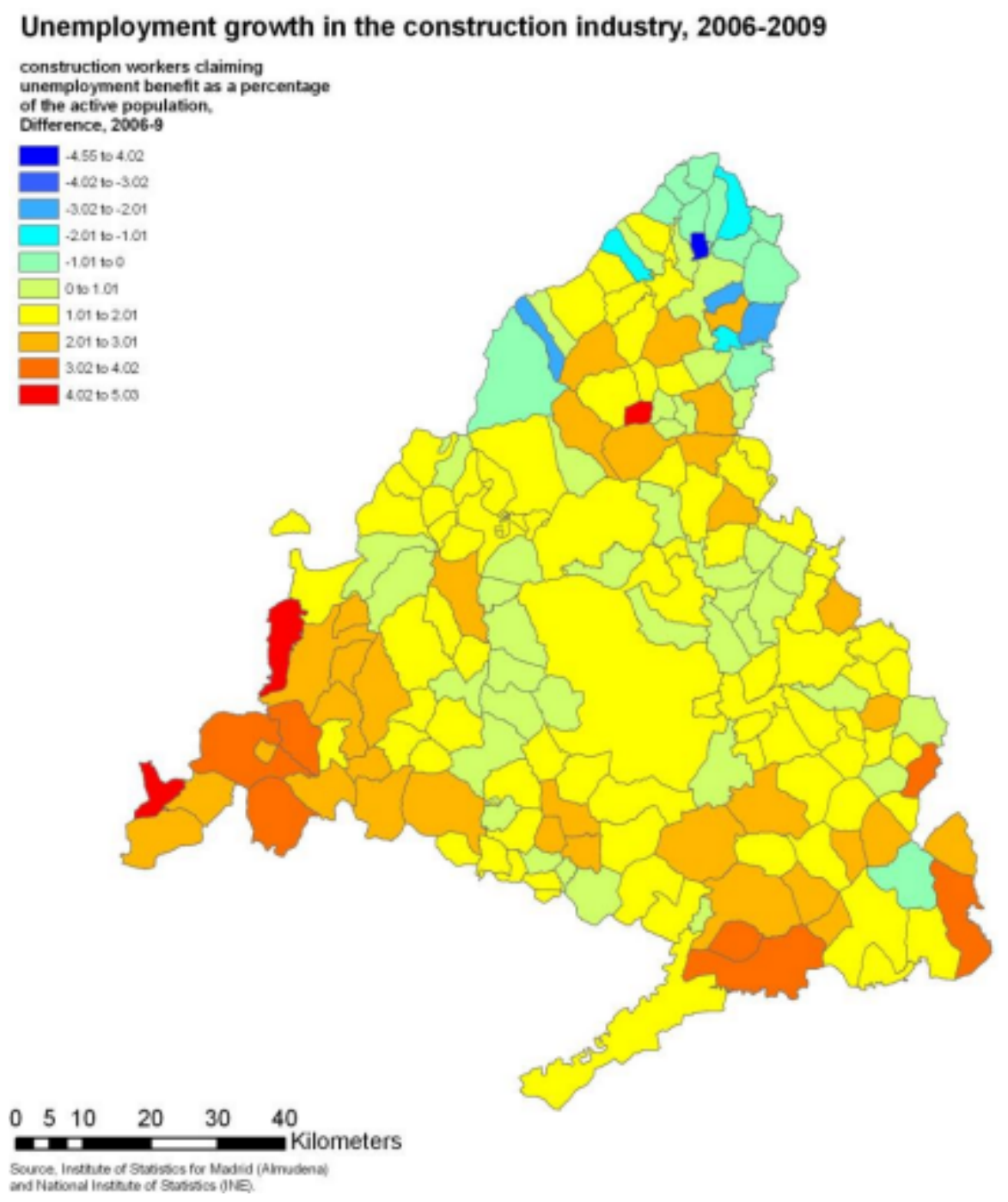

As Figure 7 clearly shows, the collapse of the construction industry responsible for the extensive development of recent years has been dramatic and has not affected all parts of the region equally. The traditionally low income rural agricultural areas of Somosierra, in the northern point of the region triangle, have seen the percentage of the active population formerly employed in construction and now claiming unemployment benefit decrease, in some cases substantially (dark blue to green shaded). But in the western municipalities (Sierra Oeste), the opposite has occurred, with up to $5 \%$ more of the active population claiming benefits in 2009 than in 2006. 
The contrast between these two rural areas (both Local Action Group territories in receipt of rural development funding) in their response to the collapse of the construction industry is interesting. It is also of interest that there is no immediately obvious correlation between areas of intensive recent development (see Figure 5) and areas now showing high increases in construction sector unemployment. The contrasting pattern of regional unemployment resulting from the collapse of the construction industry suggests that the construction boom has not benefited the regional economy evenly. Some of the lowest income areas (e.g., Ambite, Colmenar de Oreja, Estremera and Villaconejos) of the CM have been the worst affected. Through the boom inmobiliario, the CM has paid a heavy price for the short-term benefit of, one suspects, a very few $[31,55]$.

Figure 8. Growth of automobiles, 1998-2008.

\section{Automobiles (not commercial vehicles or motorcycles) per capita increase, 1998 - 2008}
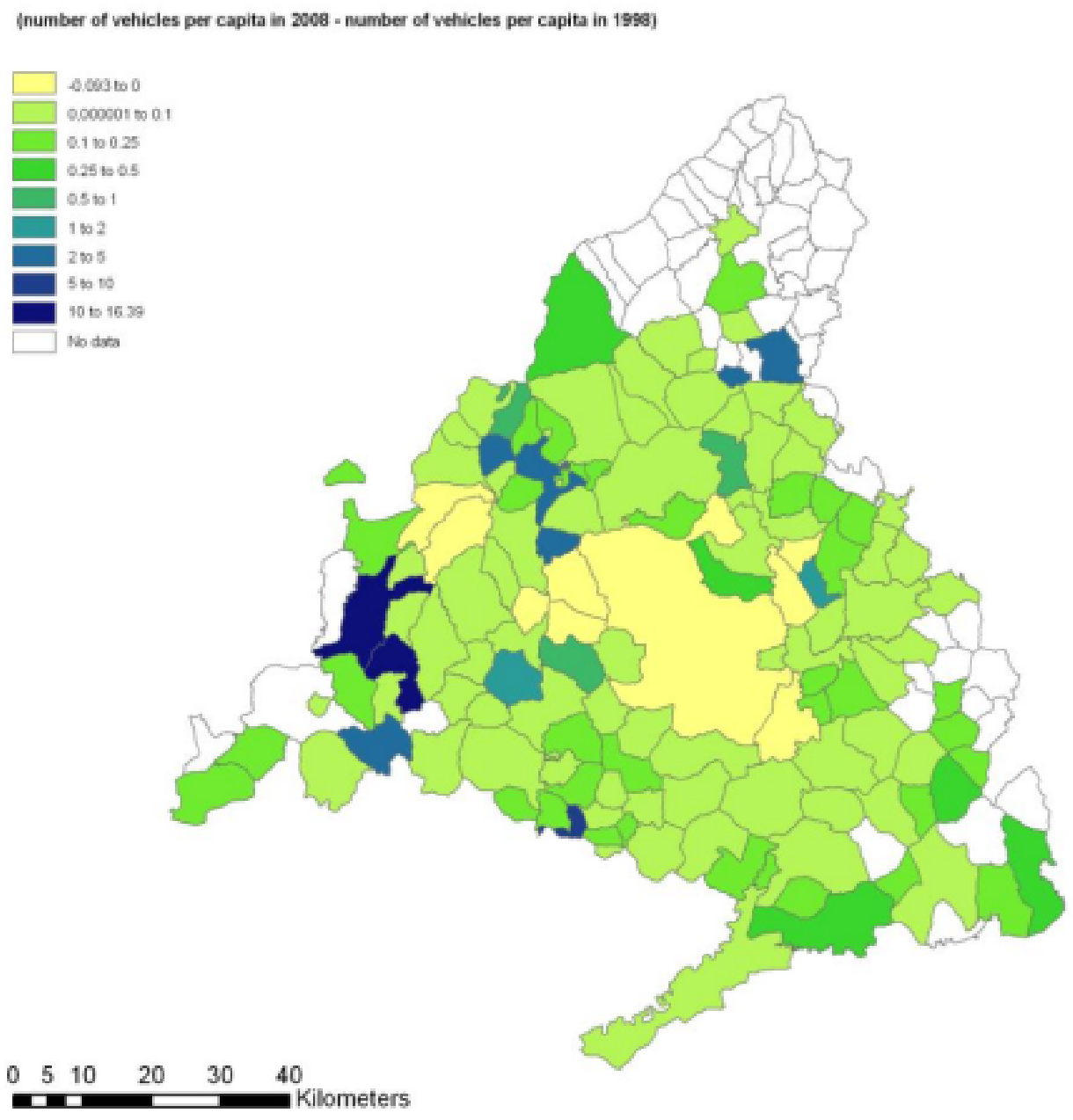

Source Anunis Erononsioe de la Cains. 2000

\subsection{Increased Motorized Transport}

The CM, in common with most parts of the developed world, has experienced strong growth both of personal car use and vehicular transportation generally in recent years. The growth of low density residential areas in Madrid has been documented by authors such as Garcia and Gutierrez [52], who have also noted the increasing trend towards private car use, especially for shorter journeys between 
outlying population centres [18]. To obtain an idea of the level of increase of personal car use in the $\mathrm{CM}$, data from the Caixa's (a major Spanish bank) yearly statistical report have been explored. These results, showing difference between numbers of automobiles (not commercial vehicles or motorcycles) per capita 1998-2008 (Figure 8 and Appendix 4) do not paint a very encouraging picture, with increased numbers of motor vehicles almost everywhere, though in most municipalities the increases have been very slight (less than 0.1 car per inhabitant). It is likely that some of the more extreme values (an increase of 16.39 cars per head between 1998 and 2008 in Colmenar de Arroyo) are due to the relocation of car-dealers premises out of the city centre to rural areas for tax reasons, as well as city dwellers registering their cars at their second homes in order to pay lower vehicle licensing costs. However, it is notable that some of the largest increases are in precisely the areas that showed the greatest growth of artificial surfaces and the most substantial reduction in natural and agricultural areas (see Figures 5 and 6).

Now it may be that the strong increases in automobiles per capita between 1998 and 2008 in municipalities of the north western sierra such as Collado Mediano, Moralzarzal and Torrelodones may be indirectly reflecting the increased construction observed between 1990 and 2000 (Figure 5 and Appendix 1). More second homes probably means that more cars per capita are registered in these areas. Nonetheless, these basic results are sufficient to begin asking questions about sustainability in these areas. This is the objective we have wanted to draw out of this article-by application of some basic indicators areas can be earmarked for future action. These areas, developed through the discussion of the previous section in reference to the statistics shown in Figures 5-8 and Appendices 1-4 we will denote "Sustainability Action Areas" (Figure 9).

\section{Conclusions: Sustainability Action Areas}

In the concluding part of this article, the indicators discussed in the preceding section have been aggregated into a single map (Figure 9, see also Appendix 5) through map overlay techniques. The aim of this is to begin to distil the large body of information on tendencies, about which most stakeholders identified were in agreement, into concentrated areas of focus. It is not suggested that Figure 9 would in itself serve as a map for administration of sustainability actions, rather that the "hotspots" observed in this map should indicate the municipalities that might usefully be grouped for particular target actions, such as reduction of private vehicle use or control of urban sprawl.

The key argument here is that progress can be made from the bottom-up, based on actual observable tendencies that must be managed through collective action where they occur, rather than by "bolting on" additional administrative responsibilities from the top-down across the whole territory. This process aims to empower local groups in the territory, charging them with assessing their own sustainability and providing their own solutions. In contrast to other processes, this must be undertaken collectively. This article may serve as a baseline study for establishing sustainability action groups for such collective action in the relevant areas, which can then themselves undertake rapid appraisal work to define achievable objectives to enhance sustainability. This approach has paid dividends in many parts of the world [53]. 
Figure 9. Areas of proposed action for sustainability.

\section{Sustainability action areas 2010}

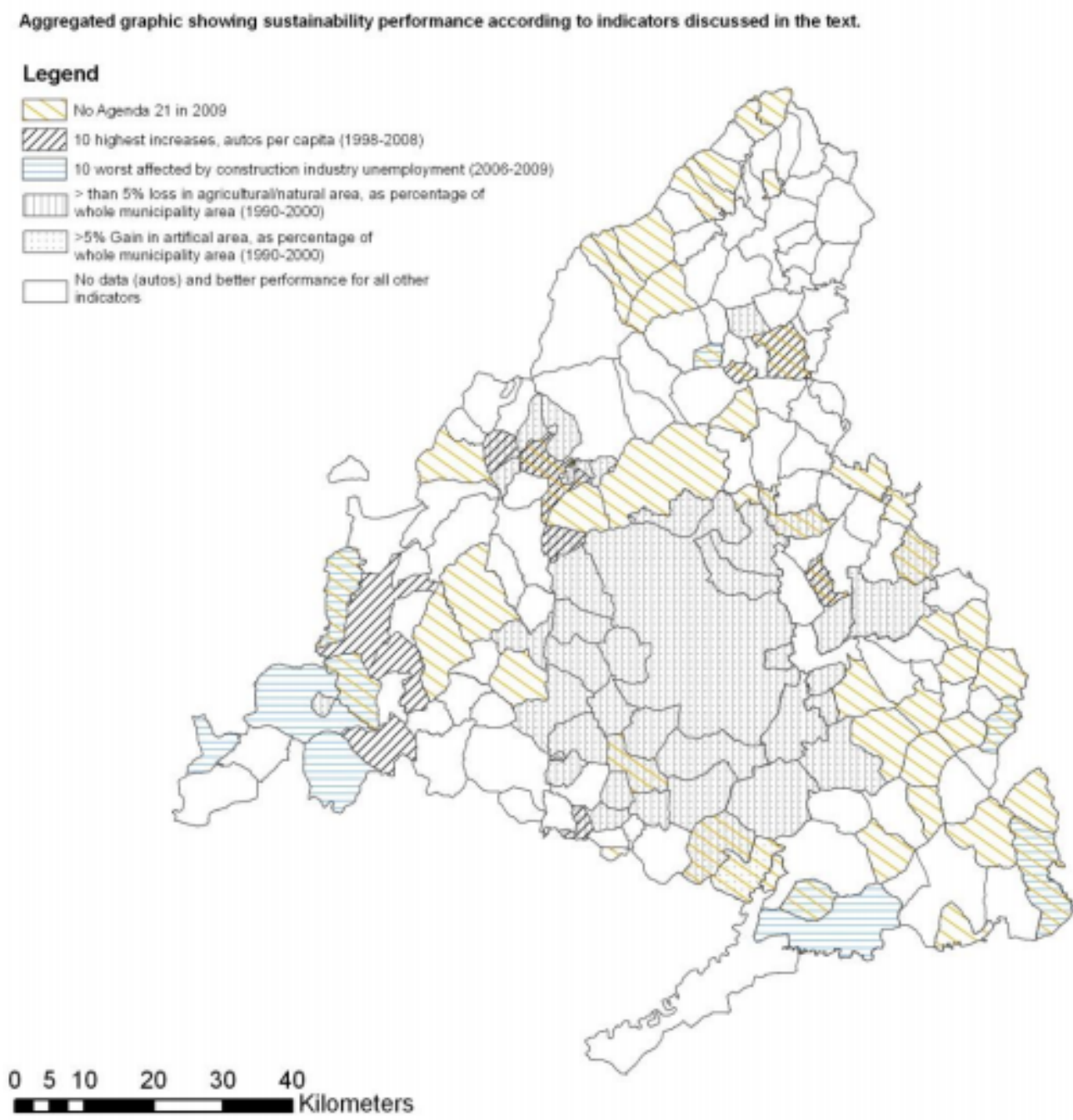

Soutce Anuavio Eronomino de la Caisa ras

With reference to Figure 9 and Appendix 5, the following areas can be identified:

(1) At the western edge of the core urban area, municipalities of Arroyomolinos, Móstoles, Villaviciosa de Odón, Boadilla del Monte, Majadahonda, Las Rozas and Villanueva de la Cañada experienced large increases in artificial areas 1990-2000 and corresponding loss of natural/agricultural land.

(2) To the west of the CM, the municipalities of the SIERRA OESTE Local Action Group territory perform poorly in the various indicators. Rozas de Puerto Real, Villa del Prado, San Martín de Valdeiglesias, Villamaqueda and Navas del Rey have suffered strong growth in construction industry unemployment following the collapse of the industry. Of these, Villamaqueda and Navas del Rey have not yet initiated Agenda 21. Navalagamella and the adjacent municipality of Valdemorillo (outside of the SIERRA OESTE Local Action Group) have also not begun this process. The municipalities of Robledo de 
Chavela, Colmenar de Arroyo and Aldea del Fresno have experienced dramatic increases in automobiles per capita since 1998.

(3) To the East and Southeast of Madrid capital, there has been generally poor compliance with Agenda 21. Of these, Ambite and Estremera have suffered in the construction industry downturn.

(4) To the south of Madrid city, municipalities such as Fuenlabrada, Pinto, Valdemoro and Ciempozuelos have seen large increases in occupation of the territory by artificial surfaces relating to peripheral residential development and expansion of infrastructures and associated logistics and light industry. Fuenlabrada, Valdemoro, Ciempozuelos, and Titulcia lack Agenda 21.

(5) To the north west of the core city, in the middle and upper valley of the river Guadarrama, the municipalities of Torrelodones, Moralzarzal, El Boalo, Becerril de la Sierra, Collado Mediano and Alpedrete have seen extensive development since 1990. Of these, Collado Mediano, Moralzarzal and Torrelodones have seen dramatic increases in automobiles since 1998. Additionally, Moralzarzal has not begun to implement Agenda 21.

(6) To the east of the core city, major development has taken place not only in the Henares corridor in Coslada, Alcalá de Henares and Torrejón de Ardoz but also to the north, in the municipalities of Meco and Ajalvir. Neither of these two municipalities has begun the Agenda 21 process, and Ajalvir has seen a strong increase in automobiles per capita since 1998.

(7) To the north east of the core city, Alcobendas, San Sebastian de los Reyes, Algete and Tres Cantos have seen substantial development in the period 1990-2000. Of these, Algete lacks Agenda 21.

(8) In the north of the region, particularly in the mountainous north-west edge of the CM, there has been generally poor uptake of Agenda 21.

(9) In the center north of the region, the municipality of La Cabrera, an area of outstanding natural value, has seen extensive development 1990-2000. Neighboring municipalities of Torrelaguna and Venturada have seen strong per capita increases in automobiles since 1998 and lack Agenda 21, like Navalafuente, which has also been hard hit by construction industry job losses.

The nine "Sustainability Action Areas" proposed are clearly not an exhaustive list and can scarcely be considered to reflect the complex range of dynamic land use changes to which the $\mathrm{CM}$ has been subjected in the last 20 years. However, they are sufficient to allow us to move away from the confused domain of debate and analysis into the sphere of concerted policy action. As we have seen, different dynamics are manifest in particular areas, and it is these dynamics that need to inform us as to where action for sustainable development is most necessary, and what precise action is needed to respond to each particular challenge.

The approach suggested here, which has certain similarities to methodologies adopted by rural development workers since the 1990s [53], focuses on bottom up appraisal of sustainability threats to the territory by local groups. Such groups cannot emerge where they are most necessary, if zones tending particularly toward unsustainability (hotspots) are not first identified. On the basis of the 
successful "opening up" of the problem domain over the last six years (inclusion of marginalized stakeholders in the debate about issues of broad consensus), we have attempted to define these unsustainability hotspots, here denominated "Sustainability Action Areas". It is now appropriate to move to the next stage of the process, and begin to implement sustainability actions in the relevant areas. It is important to emphasize that the Spanish case forming the basis of this study is likely to be applicable to other parts of the world where achieving consensus over territorial management issues has proved particularly difficult.

In the CM, municipalities need to be grouped together according to the threats they face and encouraged to work together to produce sustainability action plans based on measurable indicators of sustainability. It is important that the indicators are developed by the municipalities themselves in response to their particular capabilities and sets of circumstances, not imposed by the regional government. However they also need to take into account shared regional threats to sustainability, and not become tied down by purely local concerns. Action groups like the Observatory for a Culture of the Territory (OCT), recently established to continue the work of the European Union FP6 project ISBP, need to take this model into forward into the arena of public policy by negotiating with Madrid land planning stakeholders at all levels. In Spain's highly devolved democratic system, only collaborative planning at the appropriate level of governance can hope to respond adequately to the tremendous challenges that the Autonomous Community of Madrid now faces.

\section{Acknowledgements}

We would like to acknowledge all of the stakeholders that contributed to this research under the TiGrESS and ISBP projects, culminating in the "1st Workshops on Analysis and Reflection on the Territorial Model of the Region of Madrid'. Out of these encouraging discussions, this article emerged.

We would like to thank: the Ministry of Environment and Rural Affairs; Regional politicians of the 3 major political parties: PP, PSOE and IU. We are also particularly grateful for the contribution made by Regional authorities, notably the departments of Territorial Planning, Rural Development, and, Drover Tracks in the Madrid Government; and the departments of Territorial Policy and Agrarian Parks in the Catalonian Government.

We have drawn information and ideas from Civil Society Organisations: ecologist groups, consumer groups, non-governmental associations, farmer's trade unions, Local Actions Groups, and, local governments of municipalities in the region of Madrid, notably as Rivas-Vaciamadrid, Olmeda de las Fuentes, and Villaviciosa de Odón.

Among the academic Institutions contributing to the work, we acknowledge specially the assistance of the department of Rural Planning at the UPM as well as the Faculty of Agronomy at the UPM. We also thank the department of Geography at the UAH, UCM and UAM, as well as the URJC, UC3, and, Universitat de Valencia. We are grateful to the Commission of the EU (D.G. Research) for funding support.

The courage, vision and commitment of numerous individuals representing the above listed organisations have allowed bridges to be built between stakeholder groups and new entities, like the recently formed Observatory for a Culture of the Territory, to emerge. 


\section{References and Notes}

1. Harris, D.R. First farmers were colonists after all. British Archaeology 1997, No. 27.

2. Brundtland, G. Our Common Future: Towards Sustainable Development; The World Commission on Environment and Development, The United Nations: Geneva, Switzerland, 1987; Available online: http://www.un-documents.net/wced-ocf.htm (accessed on 20 March 2009).

3. Hernandez-Jimenez, V.; Winder, N.P. Knowledge integration and power relations: Pathways to sustainability in Madrid. In Beyond the Rural-Urban Divide: Cross-Continental Perspectives on the Differentiated Countryside and Its Regulation; Andersson, K., Lehtola, M., Eklund, E., Salmi, P., Eds.; Emerald Group Publishing Limited: London, UK, 2009.

4. Antrop, M. Landscape change and the urbanisation process in Europe. Landscape Urban Plan. 2004, 67, 9-26.

5. Ley 2/2005 de modificación de la ley 9/2001; Boletín Oficial de La Comunidad de Madrid BOCM: Madrid, Spain, 2005.

6. Ley 9/2001 del Suelo de la Comunidad de Madrid; Boletín Oficial de La Comunidad de Madrid BOCM: Madrid, Spain, 2001.

7. Antrop, M. Sustainable landscapes: Contradiction, fiction or utopia? Landscape Urban Plan. 2006, 75, 187-197.

8. Haberl, H.; Wackernagel, M.; Wrbka, T. Land use and sustainability indicators: An introduction. Land Use Policy 2004, 21, 193-198.

9. TiGrESS Project Final Report; Winder, N.P., Ed.; European Commission and University of Newcastle: Newcastle Upon Tyne, UK, 2006.

10. Winder, N.P. Innovation and metastability: A systems model. Ecol. Soc. 2007, 12, 28.

11. Cartledge, K.; Dürrwächter, C.; Hernandez-Jimenez, V.; Winder, N.P. Making sure you solve the right problem. Ecol. Soc.2009, 14, 3.

12. Plata Rocha, W.; Gómez-Delgado, M.; Bosque Sendra, J. Cambios de usos del suelo y expansión urbana en la Comunidad de Madrid 1990-2000. Scripta Nova 2009, 13, No. 293.

13. Estudio Sobre la Ocupación de Suelo por Usos Urbano-industriales, Aplicado a la Comunidad de Madrid; Naredo, J., Garcia Zaldivar, R., Eds.; Spanish Ministry of Environment and Polytechnic University of Madrid: Madrid, Spain, 2008.

14. Urban Sprawl in Europe-The Ignored Challenge; Report No. 10; Environmental European Agency (EEA): Copenhagen, Denmark, 2006.

15. Regional Policy; Directorate General for Regional Policy of the European Commission: Brussels, Belgium, 2004.

16. Cambio de Ocupación del Suelo en España: Implicaciones Para la Sostenibilidad. Principales Resultados a Nivel Nacional y Por Comunidades Autónomas; Spanish Observatory for Sustainability and University of Alcala: Alcala de Henarés, Madrid, Spain, 2006.

17. Barredo, J.I.; Gómez-Delgado, M. Towards a set of IPCC SRES urban land-use scenarios: Modelling urban land-use in the Madrid region. In Modelling Environmental Dynamics; Paegelow, M., Camacho Olmedo, M.T., Eds.; Springer: New York, NY, USA, 2006. 
18. García Palomares, J.C.; Gutiérrez Puebla, J. Pautas de la movilidad en el área metropolitana de Madrid. Cuadernos de Geografia 2007, 81-82, 7-30.

19. Serrano Cambronero, M.; Gago García, C.; Anton Burgos, F.J. Impacto Territorial de las Carreteras Orbitales de la Comunidad de Madrid. Dirección General de Investigación; Consejería de Educación de la Comunidad de Madrid: Madrid, Spain, 2002.

20. Serrano Cambronero, M.; Gago García, C.; Anton Burgos, F.J. Implicaciones Territoriales de los Trazados de las Carreteras Orbitales de la Comunidad de Madrid Mediante Teledetección: Bases Metodológicas. In Proceedings of the X Congreso Nacional de Teledetección, Cáceres, Spain, 17-19 September 2003.

21. López de Lucio, R. Transformaciones territoriales recientes en la región urbana de Madrid. Urban 2003, 8, 124-161.

22. López de Lucio, R. Morfología y características de las nuevas periferias. Nueve paisajes residenciales en la región urbana de Madrid. Urban 2004, 9, 56-80.

23. Mendez G. del Valle, R. Crisis económica y difusión industrial en la aglomeración de Madrid. An. de Geogr. de la UCM 1983, 3, 173-195.

24. Gutiérrez Puebla, J. Accesibilidad y descentralización en el espacio metropolitano madrileño. An. de Geogr. de la UCM. 1992, 12, 325-331.

25. de Santiago Rodríguez, E. El sector logístico y la gestión de los flujos globales en la región metropolitana de Madrid. Scripta Nova. 2008, 12, No. 259.

26. Diaz, J.; Hewitt, R. El territorio como bien de consumo: las grandes superficies comerciales en el contexto metropolitano y su implicación para el desarrollo urbano sostenible. In Proceedings of the Conference on Ciudad, Territorio y Paisaje: Una Mirada Multidisciplinar, Madrid, Spain, 5-7 May 2010.

27. Holling, C.S. Resilience and stability of ecological systems. Annu. Rev. Ecol. Syst. 1973, 4, 1-23.

28. Folke, C.; Hahn, T.; Olsson, P.; Norberg, J. Adaptive governance of social-ecological knowledge. Annu. Rev. Environ. Res. 2005, 30, 441-473.

29. Winder, N.P. Integrative research as appreciative system. Syst. Res. Behav. Sci. 2005, 22, 299-309.

30. Aldana, A.T. Cartografía de los cambios en las cubiertas artificiales de la Comunidad de Madrid-España 1987-1997. Revista Forestal Latinoamericana. 2005, 37, 59-86.

31. Naredo, J. El aterrizaje inmobiliario: El boom inmobiliario en España y sus consecuencias. Boletín de Ciudades para un Futuro más Sostenible, 10 July 2008.

32. Hernandez-Jimenez, V.; Ocón, B.; Encinas, M.A.; Pereira, D.; Winder, N.P. Planificación participativa en el entorno de las grandes ciudades. In Cohesión e Inteligencia Territorial; Farinós, J., Romero, J., Salom, J., Eds.; Universitat de Valencia: Valencia, Spain, 2009.

33. Gonzalez Alonso, S. 20 Años de Política Territorial en España. Tecno Ambiente 2009, 19, $43-52$.

34. Hildenbrand, A. La política de ordenación del territorio de las Comunidades Autónomas: Balance crítico y propuestas para la mejora de su eficacia. Revista de derecho urbanístico y medio ambiente 2006, 40, 79-140.

35. Madrid 21; Agencia Ambiental de la Comunidad Autónoma de Madrid: Madrid, Spain, 1993. 
36. Fundicot. Bases del Plan Regional de Estrategia Territorial de la Comunidad de Madrid; Asociación Interprofesional de Ordenación del Territorio: Madrid, Spain, 1997.

37. Fernández Muñoz, S. Participación pública, gobierno del territorio y paisaje en la Comunidad de Madrid. Boletín de la Asociación de Geógrafos Españoles 2008, 46, 97-119.

38. Orive, L. Paisajes Rotos. Ecosostenible 2008, 45, 35-42.

39. Izquierdo, J. Asturias: Región Agropolitana; KRK Ediciones: Oviedo, Spain, 2008.

40. Leboreiro, A. De la teoría a la práctica en la planificación territorial. Urban 1999, 3, 68-79.

41. Deal, B.; Pallathucheril, V. Sustainability and urban dynamics: Assessing future impacts on ecosystem services. Sustainability 2009, 1, 346-362.

42. Nel·Lo, O. La Nova Politica Territorial de Catalunya; Generalitat de Catalunya: Barcelona, Catalunya, Spain, 2004.

43. La Catalunya del Futur; EL PAIS - Catalonia Section: Barcelona, Catalonia, Spain, 15 May 2009.

44. Constitución Española; Gobierno de España: Madrid, Spain, 1978.

45. Mata Olmo, R.; Sanz Herraiz, C. Atlas de los Paisajes de España; Ministerio de Medio Ambiente: Madrid, Spain, 2006.

46. Gobierno de España. Ley 45/2007 de Desarrollo Sostenible del Medio Rural; Boletín Oficial del Estado Español BOE: Madrid, Spain, 2007.

47. Galve Martín, A.; Sancho Comíns, J. La Sierra Norte de Madrid: aspectos generales de su estructura agraria. Estudios Geográficos 1993, 211, 209-235.

48. Bullón Mata, T. Los paisajes de Madrid. Cometario sobre un texto inédito de Manuel de Terán Álvarez. Eria 2008, 76, 197-211.

49. CIMAS - Observatorio para el Desarrollo de la Ciudadanía. Agenda Local 21 y su Aplicación en la Comunidad de Madrid; Instituto de Estudios Políticos para América Latina y África (IEPALA): Madrid, Spain, 2004.

50. CIMAS - Observatorio para el Desarrollo de la Ciudadanía. Desarrollo Sostenible y Agenda 21 Local: Prácticas, Metodología y Teoría; Instituto de Estudios Políticos para América Latina y África (IEPALA): Madrid, Spain, 2004.

51. Irwin, E.G.; Geoghegan, J. Theory, data, methods: Developing spatially explicit economic models of land use change. Agr. Ecosyst. Environ. 2001, 85, 7-23.

52. García Palomares, J.C.; Gutiérrez Puebla, J. La ciudad dispersa: Cambios recientes en los espacios residenciales de la Comunidad de Madrid. An. de Geografia. 2007, 271, 45-67.

53. Chambers, R. Whose Reality Counts? Putting the First Last; ITDG Publishing: London, UK, 1997.

54. Data Service for CORINE Land Cover CLC1990 100 m; European Environmental Agency(EEA): Copenhagen, Denmark, 2007; Available online: http://dataservice.eea.europa.eu/dataservice/ metadetails.asp?id=1010 (accessed on 1 February 2010).

55. Cartografia del Suelo; El PAIS—Madrid Section: Madrid, Spain, 24 December 2004. 


\section{Appendix}

Appendix 1. Madrid municipalities: artificial land cover as a percentage of whole municipal land area, increases by 5\% or more 1990-2000.

\begin{tabular}{|c|c|c|c|c|c|c|}
\hline Municipality & $\begin{array}{l}\text { Total area } \\
\text { (hectares) }\end{array}$ & $\begin{array}{c}\text { Area of } \\
\text { artificial } \\
\text { land cover } \\
1990 \\
\text { (hectares) }\end{array}$ & $\begin{array}{c}\text { Area of } \\
\text { artificial } \\
\text { land cover } \\
2000 \\
\text { (hectares) }\end{array}$ & $\begin{array}{c}\text { Artificial } \\
\text { land cover } \\
1990 \text { as \% } \\
\text { total area } \\
1990\end{array}$ & $\begin{array}{c}\text { Artificial } \\
\text { land cover } \\
2000 \text { as \% } \\
\text { total area } \\
1990 \\
\end{array}$ & $\begin{array}{c}\text { Difference } \\
\% 1990 \text { to } \\
\% 2000\end{array}$ \\
\hline Coslada & $1,201.52$ & 570.56 & 940.69 & 47.49 & 78.29 & 30.81 \\
\hline Leganés & $4,324.72$ & 790.53 & $1,743.21$ & 18.28 & 40.31 & 22.03 \\
\hline Pozuelo de Alarcón & $4,311.67$ & $1,764.91$ & $2,709.02$ & 40.93 & 62.83 & 21.90 \\
\hline Alcorcón & $3,358.38$ & 728.16 & $1,365.03$ & 21.68 & 40.65 & 18.96 \\
\hline Alcobendas & $4,522.31$ & $1,287.30$ & $2,091.94$ & 28.47 & 46.26 & 17.79 \\
\hline Móstoles & $4,493.91$ & 698.14 & $1,454.46$ & 15.54 & 32.37 & 16.83 \\
\hline Alcalá de Henares & $8,834.58$ & $1,603.72$ & $2,871.65$ & 18.15 & 32.50 & 14.35 \\
\hline Rozas de Madrid (Las) & $5,826.43$ & $1,555.10$ & $2,372.64$ & 26.69 & 40.72 & 14.03 \\
\hline Rivas-Vaciamadrid & $6,729.40$ & 357.01 & $1,243.56$ & 5.31 & 18.48 & 13.17 \\
\hline Fuenlabrada & $3,917.32$ & $1,085.10$ & $1,598.80$ & 27.70 & 40.81 & 13.11 \\
\hline Torrejón de Ardoz & $3,242.16$ & $1,895.41$ & $2,313.01$ & 58.46 & 71.34 & 12.88 \\
\hline Ajalvir & $1,974.13$ & 105.07 & 335.70 & 5.32 & 17.00 & 11.68 \\
\hline Majadahonda & $3,846.58$ & 535.02 & 983.53 & 13.91 & 25.57 & 11.66 \\
\hline Boadilla del Monte & $4,740.93$ & $1,197.32$ & $1,741.77$ & 25.25 & 36.74 & 11.48 \\
\hline Madrid & $60,463.06$ & $22,209.88$ & $28,740.14$ & 36.73 & 47.53 & 10.80 \\
\hline San Sebastián de los Reyes & $5,921.39$ & 952.79 & $1,587.59$ & 16.09 & 26.81 & 10.72 \\
\hline Mejorada del Campo & $1,793.48$ & 259.37 & 449.33 & 14.46 & 25.05 & 10.59 \\
\hline San Martín de la Vega & $10,509.17$ & 570.20 & $1,666.69$ & 5.43 & 15.86 & 10.43 \\
\hline Villanueva de la Cañada & $3,477.03$ & 408.99 & 745.21 & 11.76 & 21.43 & 9.67 \\
\hline Getafe & $7,858.95$ & $1,675.68$ & $2,423.65$ & 21.32 & 30.84 & 9.52 \\
\hline Boalo (El) & $3,946.16$ & 111.34 & 479.79 & 2.82 & 12.16 & 9.34 \\
\hline Arroyomolinos & $2,079.31$ & 18.21 & 209.11 & 0.88 & 10.06 & 9.18 \\
\hline Griñón & $1,708.72$ & 130.72 & 283.95 & 7.65 & 16.62 & 8.97 \\
\hline Parla & $2,497.78$ & 291.69 & 514.67 & 11.68 & 20.61 & 8.93 \\
\hline Pinto & $6,199.83$ & 448.97 & 967.14 & 7.24 & 15.60 & 8.36 \\
\hline Humanes de Madrid & $1,967.30$ & 234.54 & 393.28 & 11.92 & 19.99 & 8.07 \\
\hline Pelayos de la Presa & 751.99 & 200.94 & 261.11 & 26.72 & 34.72 & 8.00 \\
\hline Becerril de la Sierra & 2952.81 & 175.92 & 404.40 & 5.96 & 13.70 & 7.74 \\
\hline Velilla de San Antonio & 1437.33 & 321.24 & 427.29 & 22.35 & 29.73 & 7.38 \\
\hline Villaviciosa de Odón & $6,817.33$ & 820.09 & $1,313.84$ & 12.03 & 19.27 & 7.24 \\
\hline Moralzarzal & $4,361.95$ & 114.61 & 385.10 & 2.63 & 8.83 & 6.20 \\
\hline Cabrera (La) & $2,213.96$ & 153.21 & 277.25 & 6.92 & 12.52 & 5.60 \\
\hline Serranillos del Valle & $1,303.14$ & 10.88 & 83.57 & 0.83 & 6.41 & 5.58 \\
\hline Algete & $3,792.22$ & 411.56 & 622.73 & 10.85 & 16.42 & 5.57 \\
\hline Arganda del Rey & $8,027.97$ & 988.10 & $1,432.47$ & 12.31 & 17.84 & 5.54 \\
\hline Tres Cantos & $3,793.56$ & 515.72 & 725.57 & 13.59 & 19.13 & 5.53 \\
\hline
\end{tabular}


Appendix 1. Cont.

\begin{tabular}{|c|c|c|c|c|c|c|}
\hline Municipality & $\begin{array}{c}\text { Total area } \\
\text { (hectares) }\end{array}$ & $\begin{array}{c}\text { Area of } \\
\text { artificial } \\
\text { land cover } \\
\mathbf{1 9 9 0} \\
\text { (hectares) }\end{array}$ & $\begin{array}{c}\text { Area of } \\
\text { artificial } \\
\text { land cover } \\
\mathbf{2 0 0 0} \\
\text { (hectares) }\end{array}$ & $\begin{array}{c}\text { Artificial } \\
\text { land cover } \\
\mathbf{1 9 9 0} \text { as \% } \\
\text { total area } \\
\mathbf{1 9 9 0}\end{array}$ & $\begin{array}{c}\text { Artificial } \\
\text { land cover } \\
\mathbf{2 0 0 0} \text { as \% } \\
\text { total area } \\
\mathbf{1 9 9 0}\end{array}$ & $\begin{array}{c}\text { Difference } \\
\mathbf{1 9 9 0} \text { to } \\
\mathbf{2 0 0 0}\end{array}$ \\
\hline Meco & $3,492.71$ & 46.32 & 232.44 & 1.33 & 6.66 & 5.33 \\
\hline Torrelodones & $2,173.42$ & 700.12 & 814.21 & 32.21 & 37.46 & 5.25 \\
\hline Valdemoro & $6,417.26$ & 645.27 & 978.77 & 10.06 & 15.25 & 5.20 \\
\hline Collado Mediano & $2,231.08$ & 193.54 & 307.18 & 8.67 & 13.77 & 5.09 \\
\hline Ciempozuelos & $4,937.36$ & 205.45 & 456.59 & 4.16 & 9.25 & 5.09 \\
\hline Alpedrete & $1,266.08$ & 367.09 & 431.45 & 28.99 & 34.08 & 5.08 \\
\hline
\end{tabular}

Appendix 2. Madrid municipalities: agricultural and natural land cover as a percentage of whole municipal land area, decreases by $5 \%$ or more $1990-2000$.

\begin{tabular}{|c|c|c|c|c|c|c|}
\hline Municipality & $\begin{array}{c}\text { Total area } \\
\text { (hectares) }\end{array}$ & $\begin{array}{c}\text { Area of } \\
\text { nat/agric } \\
\text { land cover } \\
\mathbf{1 9 9 0} \\
\text { (hectares) }\end{array}$ & $\begin{array}{c}\text { Area of } \\
\text { nat/agric } \\
\text { land cover } \\
\mathbf{2 0 0 0} \\
\text { (hectares) }\end{array}$ & $\begin{array}{c}\text { Nat/agric } \\
\text { land cover } \\
\mathbf{1 9 9 0} \text { as \% } \\
\text { total area }\end{array}$ & $\begin{array}{c}\text { Nat/agric } \\
\text { land cover } \\
\mathbf{2 0 0 0} \text { as \% } \\
\text { total area }\end{array}$ & $\begin{array}{c}\text { difference \%1990 } \\
\text { to \%2000 }\end{array}$ \\
\hline Coslada & $1,201.52$ & 630.97 & 260.83 & 52.51 & 21.71 & -30.81 \\
\hline Leganés & $4,324.72$ & $3,522.59$ & $2,569.91$ & 81.45 & 59.42 & -22.03 \\
\hline Pozuelo de Alarcón & $4,311.67$ & $2,546.77$ & $1,602.65$ & 59.07 & 37.17 & -21.90 \\
\hline Alcorcón & $3,358.38$ & $2,630.22$ & $1,993.35$ & 78.32 & 59.35 & -18.96 \\
\hline Alcobendas & $4,522.31$ & $3,235.01$ & $2,430.37$ & 71.53 & 53.74 & -17.79 \\
\hline Móstoles & $4,493.91$ & $3,795.78$ & $3,039.45$ & 84.46 & 67.63 & -16.83 \\
\hline Rivas-Vaciamadrid & $6,729.40$ & $6,204.44$ & $5,214.98$ & 92.20 & 77.50 & -14.70 \\
\hline Alcalá de Henares & $8,834.58$ & $7,230.85$ & $5,934.76$ & 81.85 & 67.18 & -14.67 \\
\hline Rozas de Madrid (Las) & $5,826.43$ & $4,260.87$ & $3,443.32$ & 73.13 & 59.10 & -14.03 \\
\hline Fuenlabrada & $3,917.32$ & $2,832.21$ & $2,318.52$ & 72.30 & 59.19 & -13.11 \\
\hline Torrejón de Ardoz & $3,242.16$ & $1,346.75$ & 929.15 & 41.54 & 28.66 & -12.88 \\
\hline Ajalvir & $1,974.13$ & $1,869.05$ & $1,638.43$ & 94.68 & 83.00 & -11.68 \\
\hline Majadahonda & $3,846.58$ & $3,311.56$ & $2,863.05$ & 86.09 & 74.43 & -11.66 \\
\hline Velilla de San Antonio & $1,437.33$ & $1,101.86$ & 935.12 & 76.66 & 65.06 & -11.60 \\
\hline Boadilla del Monte & $4,740.93$ & $3,543.62$ & $2,999.16$ & 74.75 & 63.26 & -11.48 \\
\hline San Martín de la Vega & $10,509.17$ & $9,884.98$ & $8,744.08$ & 94.06 & 83.20 & -10.86 \\
\hline Madrid & $60,463.06$ & $37,869.73$ & $31,339.47$ & 62.63 & 51.83 & -10.80 \\
\hline San Sebastián de los Reyes & $5,921.39$ & $4,968.61$ & $4,333.80$ & 83.91 & 73.19 & -10.72 \\
\hline Mejorada del Campo & $1,793.48$ & $1,534.11$ & $1,344.15$ & 85.54 & 74.95 & -10.59 \\
\hline Villanueva de la Cañada & $3,477.03$ & $3,068.04$ & $2,731.82$ & 88.24 & 78.57 & -9.67 \\
\hline Getafe & $7,858.95$ & $6,183.27$ & $5,426.39$ & 78.68 & 69.05 & -9.63 \\
\hline Boalo (El) & $3,946.16$ & $3,834.81$ & $3,466.37$ & 97.18 & 87.84 & -9.34 \\
\hline Arroyomolinos & $2,079.31$ & $2,061.11$ & $1,870.20$ & 99.12 & 89.94 & -9.18 \\
\hline Griñón & $1,708.72$ & $1,578.00$ & $1,424.76$ & 92.35 & 83.38 & -8.97 \\
\hline Parla & $2,497.78$ & $2,206.09$ & $1,983.11$ & 88.32 & 79.39 & -8.93 \\
\hline & & & & & & \\
\hline
\end{tabular}


Appendix 2. Cont.

\begin{tabular}{|c|c|c|c|c|c|c|}
\hline Municipality & $\begin{array}{c}\text { Total area } \\
\text { (hectares) }\end{array}$ & $\begin{array}{c}\text { Area of } \\
\text { nat/agric } \\
\text { land cover } \\
\mathbf{1 9 9 0} \\
\text { (hectares) }\end{array}$ & $\begin{array}{c}\text { Area of } \\
\text { nat/agric } \\
\text { land cover } \\
\mathbf{2 0 0 0} \\
\text { (hectares) }\end{array}$ & $\begin{array}{c}\text { Nat/agric } \\
\text { land cover } \\
\mathbf{1 9 9 0} \text { as \% } \\
\text { total area }\end{array}$ & $\begin{array}{c}\text { Nat/agric } \\
\text { land cover } \\
\mathbf{2 0 0 0} \text { as \% } \\
\text { total area }\end{array}$ & $\begin{array}{c}\text { difference \%1990 } \\
\text { to \%2000 }\end{array}$ \\
\hline Pinto & $6,199.83$ & $5,750.86$ & $5,232.69$ & 92.76 & 84.40 & -8.36 \\
\hline Humanes de Madrid & $1,967.30$ & $1,732.76$ & $1,574.02$ & 88.08 & 80.01 & -8.07 \\
\hline Pelayos de la Presa & 751.99 & 550.27 & 490.10 & 73.18 & 65.17 & -8.00 \\
\hline Becerril de la Sierra & $2,952.81$ & $2,774.39$ & $2,545.92$ & 93.96 & 86.22 & -7.74 \\
\hline Villaviciosa de Odón & $6,817.33$ & $5,997.24$ & $5,503.49$ & 87.97 & 80.73 & -7.24 \\
\hline Moralzarzal & $4,361.95$ & $4,247.34$ & $3,976.85$ & 97.37 & 91.17 & -6.20 \\
\hline Algete & $3,792.22$ & $3,380.66$ & $3,160.40$ & 89.15 & 83.34 & -5.81 \\
\hline Arganda del Rey & $8,027.97$ & $6,995.83$ & $6,537.89$ & 87.14 & 81.44 & -5.70 \\
\hline Cabrera (La) & $2,213.96$ & $2,060.75$ & $1,936.71$ & 93.08 & 87.48 & -5.60 \\
\hline Tres Cantos & $3,793.56$ & $3,277.84$ & $3,067.99$ & 86.41 & 80.87 & -5.53 \\
\hline Serranillos del Valle & $1,303.14$ & $1,288.03$ & $1,219.57$ & 98.84 & 93.59 & -5.25 \\
\hline Torrelodones & $2,173.42$ & $1,464.79$ & $1,350.70$ & 67.40 & 62.15 & -5.25 \\
\hline Collado Mediano & $2,231.08$ & $2,037.54$ & $1,923.90$ & 91.33 & 86.23 & -5.09 \\
\hline Alpedrete & $1,266.08$ & 898.99 & 834.63 & 71.01 & 65.92 & -5.08 \\
\hline Valdemoro & $6,417.26$ & $5,760.07$ & $5,438.49$ & 89.76 & 84.75 & -5.01 \\
\hline Meco & $3,492.71$ & $3,435.11$ & $3,260.26$ & 98.35 & 93.34 & -5.01 \\
\hline
\end{tabular}

Appendix 3. Madrid municipalities: ten highest increases in unemployment in the construction industry, 2006-2009.

\begin{tabular}{|c|c|c|c|c|c|c|c|}
\hline Municipality & $\begin{array}{c}\text { Active } \\
\text { population } \\
\mathbf{2 0 0 6}\end{array}$ & $\begin{array}{c}\text { Active } \\
\text { population } \\
\mathbf{2 0 0 9}\end{array}$ & $\begin{array}{c}\text { Population } \\
\text { unemployed } \\
\text { from } \\
\text { construction } \\
\mathbf{2 0 0 6}\end{array}$ & $\begin{array}{c}\text { Population } \\
\text { unemployed } \\
\text { from } \\
\text { construction } \\
\mathbf{2 0 0 9}\end{array}$ & $\begin{array}{c}\text { Population } \\
\text { unemployed } \\
\text { from } \\
\text { construction } \\
\mathbf{2 0 0 6} \text { as \% } \\
\text { of active } \\
\text { population } \\
\text { 2006 }\end{array}$ & $\begin{array}{c}\text { Population } \\
\text { unemployed } \\
\text { from } \\
\text { construction } \\
\text { 2009 as \% of } \\
\text { active } \\
\text { population } \\
\mathbf{2 0 0 9}\end{array}$ & $\begin{array}{c}\text { ifference, \% } \\
\text { population } \\
\text { unemployed } \\
\text { from } \\
\text { construction } \\
\text { (2006-09) }\end{array}$ \\
\hline Valdemaqueda & 567 & 593 & 4 & 34 & 0.71 & 5.73 & 5.03 \\
\hline Navalafuente & 592 & 805 & 6 & 41 & 1.01 & 5.09 & 4.08 \\
\hline Rozas de Puerto & & & & & & & \\
\hline Real & 208 & 247 & 0 & 10 & 0.00 & 4.05 & 4.05 \\
\hline Villaconejos & 2044 & 2250 & 17 & 103 & 0.83 & 4.58 & 3.75 \\
\hline Colmenar de Oreja & 4814 & 5724 & 56 & 272 & 1.16 & 4.75 & 3.59 \\
\hline Ambite & 212 & 349 & 0 & 12 & 0.00 & 3.44 & 3.44 \\
\hline Villa del Prado & 3779 & 4212 & 32 & 180 & 0.85 & 4.27 & 3.43 \\
\hline Navas del Rey & 1635 & 1674 & 30 & 87 & 1.83 & 5.20 & 3.36 \\
\hline $\begin{array}{c}\text { San Martín de } \\
\text { Valdeiglesias }\end{array}$ & 4865 & 5263 & 68 & 245 & 1.40 & 4.66 & 3.26 \\
\hline Estremera & 860 & 949 & 6 & 36 & 0.70 & 3.79 & 3.10 \\
\hline
\end{tabular}


Appendix 4. Madrid municipalities: ten highest increases in automobiles per capita, 1998-2008.

\begin{tabular}{|c|c|c|c|c|c|c|c|}
\hline Municipality & $\begin{array}{c}\text { Population } \\
\mathbf{( 1 9 9 8 )}\end{array}$ & $\begin{array}{c}\text { Population } \\
\mathbf{( 2 0 0 8 )}\end{array}$ & $\begin{array}{c}\text { Automobiles } \\
\mathbf{( 1 9 9 8 )}\end{array}$ & $\begin{array}{c}\text { Automobiles } \\
\mathbf{( 2 0 0 8 )}\end{array}$ & $\begin{array}{c}\text { Autos per } \\
\text { capita } \\
\mathbf{( 1 9 9 8 )}\end{array}$ & $\begin{array}{c}\text { Autos per } \\
\text { capita (2008) }\end{array}$ & $\begin{array}{c}\text { Difference, } \\
\text { autos per } \\
\text { capita } \\
\mathbf{2 0 0 8}-\mathbf{1 9 9 8}\end{array}$ \\
\hline $\begin{array}{c}\text { Robledo de } \\
\text { Chavela }\end{array}$ & 2,014 & 3,773 & 869 & 63,469 & 0.43 & 16.82 & 16.39 \\
\hline $\begin{array}{c}\text { Colmenar del } \\
\text { Arroyo }\end{array}$ & 853 & 1,348 & 228 & 18,973 & 0.27 & 14.07 & 13.81 \\
\hline $\begin{array}{c}\text { Serranillos del } \\
\text { Valle }\end{array}$ & 778 & 3,273 & 323 & 21,263 & 0.42 & 6.50 & 6.08 \\
\hline Torrelaguna & 2,558 & 4,671 & 874 & 22,894 & 0.34 & 4.90 & 4.56 \\
\hline Venturada & 639 & 1,609 & 248 & 6,600 & 0.39 & 4.10 & 3.71 \\
\hline $\begin{array}{c}\text { Collado } \\
\text { Mediano }\end{array}$ & 0 & 6,427 & 1,562 & 23,605 & 0.00 & 3.67 & 3.67 \\
\hline $\begin{array}{c}\text { Aldea del } \\
\text { Fresno }\end{array}$ & 1,308 & 2,424 & 1,036 & 8,200 & 0.79 & 3.38 & 2.59 \\
\hline Moralzarzal & 4,149 & 11,318 & 1,820 & 32,889 & 0.44 & 2.91 & 2.47 \\
\hline Torrelodones & 11,100 & 21,231 & 5,877 & 60,494 & 0.53 & 2.85 & 2.32 \\
\hline Ajalvir & 1,817 & 3,558 & 1,027 & 8,039 & 0.57 & 2.26 & 1.69 \\
\hline
\end{tabular}

Appendix 5. Sustainability Action areas and relevant indicators.

\begin{tabular}{|c|c|c|c|}
\hline Action Area $\mathbf{n}^{\circ}$ & Action Area name & Indicator & Municipalities \\
\hline \multirow[t]{2}{*}{1} & \multirow[t]{2}{*}{ Urban fringe West } & $\begin{array}{l}\text { Strong increase artificial areas } \\
1990-2000\end{array}$ & Arroyomolinos \\
\hline & & $\begin{array}{l}\text { Decline natural/agricultural areas } \\
1990-2000\end{array}$ & $\begin{array}{l}\text { Móstoles } \\
\text { Villaviciosa de Odón } \\
\text { Boadilla del Monte } \\
\text { Majadaonda } \\
\text { Las Rozas } \\
\text { Villanueva de la Cañada }\end{array}$ \\
\hline \multirow[t]{3}{*}{2} & \multirow[t]{3}{*}{ CM West } & $\begin{array}{l}\text { Strong increases in construction } \\
\text { unemployment 2006-2009 }\end{array}$ & Rozas de Puerto Real \\
\hline & & Agenda 21 not initiated by 2009 & Navalagamella \\
\hline & & $\begin{array}{l}\text { Strong growth in automobiles per capita } \\
\text { since } 1998\end{array}$ & $\begin{array}{l}\text { Valdemorillo } \\
\text { Robledo de Chavela } \\
\text { Colmenar de Arroyo } \\
\text { Aldea del Fresno } \\
\text { Villa del Prado } \\
\text { San Martín de } \\
\text { Valdeiglesias } \\
\text { Villamaqueda } \\
\text { Navas del Rey }\end{array}$ \\
\hline
\end{tabular}


Appendix 5. Cont.

\begin{tabular}{|c|c|c|c|}
\hline Action Area $\mathbf{n}^{\circ}$ & Action Area name & Indicator & Municipalities \\
\hline 3 & CM South East & $\begin{array}{l}\text { Strong increases in construction } \\
\text { unemployment 2006-2009 } \\
\text { Agenda } 21 \text { not initiated by } 2009\end{array}$ & $\begin{array}{l}\text { Municipalities bisected by } \\
\text { and east of a line drawn } \\
\text { between Los Santos de la } \\
\text { Humosa and Aranjuez }\end{array}$ \\
\hline \multirow[t]{3}{*}{4} & \multirow[t]{3}{*}{$\begin{array}{l}\text { Urban fringe and } \\
\text { Corridor South }\end{array}$} & $\begin{array}{l}\text { Strong increase artificial areas } \\
1990-2000\end{array}$ & Fuenlabrada \\
\hline & & $\begin{array}{l}\text { Decline natural/agricultural areas } \\
1990-2000\end{array}$ & Pinto \\
\hline & & Agenda 21 not initiated by 2009 & $\begin{array}{l}\text { Valdemoro } \\
\text { Getafe } \\
\text { San Martín de la Vega } \\
\text { Titulcia }\end{array}$ \\
\hline \multirow[t]{4}{*}{5} & \multirow[t]{4}{*}{ Guadarrama Valley } & $\begin{array}{l}\text { Strong increase artificial areas } \\
1990-2000\end{array}$ & Torrelodones \\
\hline & & $\begin{array}{l}\text { Decline natural/agricultural areas } \\
1990-2000\end{array}$ & Moralzarzal \\
\hline & & Agenda 21 not initiated by 2009 & El Boalo \\
\hline & & $\begin{array}{l}\text { Strong growth in automobiles per capita } \\
\text { since } 1998\end{array}$ & $\begin{array}{l}\text { Becerril de la Sierra } \\
\text { Collado Mediano } \\
\text { Alpedrete } \\
\end{array}$ \\
\hline \multirow[t]{4}{*}{6} & \multirow[t]{4}{*}{$\begin{array}{l}\text { Urban fringe and } \\
\text { Corridor East }\end{array}$} & $\begin{array}{l}\text { Strong increase artificial areas } \\
1990-2000\end{array}$ & Coslada \\
\hline & & $\begin{array}{l}\text { Decline natural/agricultural areas } \\
1990-2000\end{array}$ & Alcalá de Henares \\
\hline & & $\begin{array}{l}\text { Strong growth in automobiles per capita } \\
\text { since } 1998\end{array}$ & Torrejón de Ardoz \\
\hline & & Agenda 21 not initiated by 2009 & $\begin{array}{l}\text { Meco } \\
\text { Ajalvir }\end{array}$ \\
\hline \multirow[t]{3}{*}{7} & \multirow[t]{3}{*}{$\begin{array}{l}\text { Urban fringe and } \\
\text { Corridor North }\end{array}$} & $\begin{array}{l}\text { Strong increase artificial areas } \\
1990-2000\end{array}$ & Alcobendas, \\
\hline & & $\begin{array}{l}\text { Decline natural/agricultural areas } \\
1990-2000\end{array}$ & San Sebastián de los Reyes \\
\hline & & Agenda 21 not initiated by 2009 & $\begin{array}{l}\text { Algete } \\
\text { Tres Cantos }\end{array}$ \\
\hline 8 & CM North & Agenda 21 not initiated by 2009 & $\begin{array}{l}\text { Municipalities bisected by } \\
\text { and north of a line drawn } \\
\text { between Torrelaguna and } \\
\text { Rascafria }\end{array}$ \\
\hline
\end{tabular}


Appendix 5. Cont.

\begin{tabular}{|c|l|l|l|}
\hline Action Area n & Action Area name & \multicolumn{1}{|c|}{ Indicator } & \multicolumn{1}{|c|}{ Municipalities } \\
\hline \multirow{4}{*}{9} & \multirow{4}{*}{ CM Center North } & Strong Increase artificial areas & \\
& & La Cabrera \\
\cline { 3 - 4 } & & Decline natural/agricultural areas \\
& $1990-2000$ & Torrelaguna \\
\cline { 3 - 4 } & & Strong increases in construction & \\
& & unemployment 2006-2009 & Venturada \\
\hline & Agenda 21 not initiated by 2009 & Navalafuente \\
\hline
\end{tabular}

(C) 2010 by the authors; licensee MDPI, Basel, Switzerland. This article is an open-access article distributed under the terms and conditions of the Creative Commons Attribution license (http://creativecommons.org/licenses/by/3.0/). 